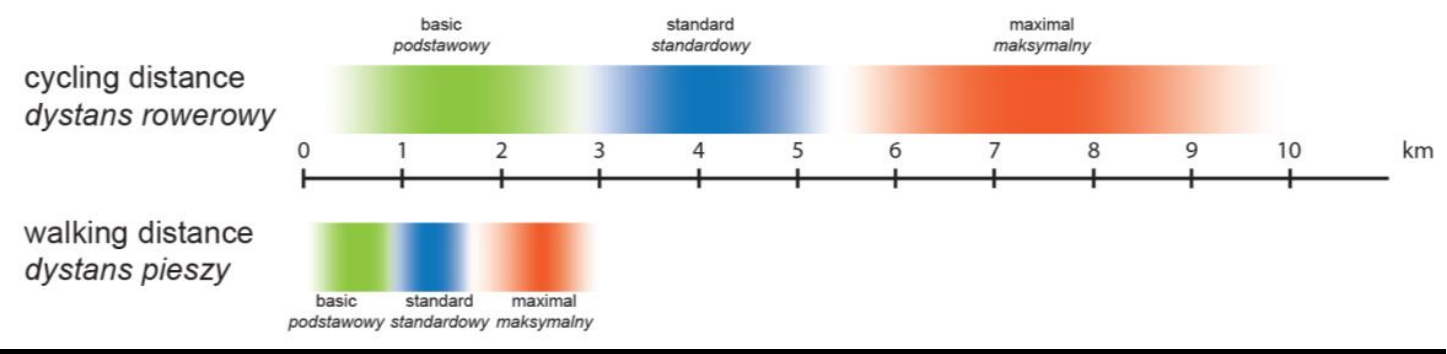

DOI: 10.21005/pif.2021.46.C-08

\title{
URBAN DISTANCES. DIMENSIONS OF URBAN UNITS AND DISTRIBUTION OF FUNCTIONS IN THE CITY IN CONTEXT OF WALKING, CYCLING AND PUBLIC TRANSPORT DISTANCES
}

\author{
DYSTANSE MIEJSKIE. WYMIARY JEDNOSTEK URBANISTYCZNYCH \\ ORAZ ROZMIESZCZENIE FUNKCJI W MIEŚCIE W KONTEKŚCIE \\ DYSTANSÓW PIESZYCH, ROWEROWYCH I TRANSPORTU PUBLICZNEGO
}

\section{Leszek S. Wiśniewski}

mgr inż. Arch./MSc. Arch.

Author's Orcid number: 0000-0001-5190-8316

Politechnika Warszawska | Warsaw University of Technology

Wydział Architektury | Faculty of Architecture

Katedra Projektowania Urbanistycznego i Krajobrazu Wiejskiego | Department of Urban Planning and Rural Landscape

\begin{abstract}
The share of various means of transport in travels within the city is not only a technological issue, but first and foremost a spatial issue. Walking and bicycle trips tend to be shorter both in terms of distance and time, compared to trips made by public transport or by car. Therefore, a question arises: how functions should be distributed of in the city to enable its inhabitants to use individual car transport as little as possible? The aim of the article is to discuss several concepts regarding walking, cycling and public transport distances and to confront these theories with data obtained in several European cities -Amsterdam, Berlin, Copenhagen, London, Paris, Warsaw and Vienna.
\end{abstract}

Key words: active mobility, chrono-urbanism, cycling distance, distances in urban theories, public transport, time as dimension in spatial planning, walking distance.

\section{STRESZCZENIE}

Udział różnych środków transportu w podróżach w mieście to nie tylko zagadnienie technologiczne, ale przede wszystkim przestrzenne. Podróże piesze i rowerowe są zazwyczaj krótsze zarówno w przestrzeni jak i w czasie w porównaniu z podróżami transportem publicznym i samochodem. Jakie zatem powinno być rozmieszczenie funkcji w mieście by jego mieszkańcy jak najrzadziej korzystali ze indywidualnego transportu samochodowego? Celem artykułu jest omówienie kilku teorii dotyczących dystansów pieszych, rowerowych i związanych z transportem publicznym oraz skonfrontowanie ich z danymi z kilku europejskich miast - Amsterdamu, Berlina, Kopenhagi, Londynu, Paryża, Warszawy oraz Wiednia.

Słowa kluczowe: aktywna mobilność, chronourbanizm, dystans pieszy, dystans rowerowy, dystanse w teoriach urbanistycznych, transport publiczny, wymiar czasu w planowaniu przestrzennym. 


\section{INTRODUCTION}

On one hand transport is one of the most important elements of spatial planning. On the other hand, however, spatial planning itself has significant impact on transport. Whether residents are more likely to choose sustainable forms of transport, such as walking, cycling or public transport, rather than individual car transport often results not only from the availability of infrastructure for a given means of transport, but also from the distance to be covered in order to reach certain facilities. Therefore, it is impossible to change urban mobility to more environmentally friendly and healthy one only by means of expanding and improving public transport or by construction of bicycle routes. The fundamental task should be to transform the urban structure in such a way that it corresponds to the distances usually covered by walk, by bike or by public transport. More attention should be given to various forms of active mobility (walking and cycling) than to public transport, which is being slightly overrated in the countries of the former Eastern Bloc. This article examines distances in urban theories from the times of Ebenezer Howard's "Garden City", to the modern concept of the "15-minute city". Those theories will later be confronted with data from traffic surveys conducted by the authorities of Amsterdam, Berlin, Copenhagen, London, Paris, Warsaw and Vienna. Issues such as average trip distance and/or time for different modes of transport will be discussed. Also preferences related to trips to certain facilities will be shown, to the extent that sufficient data is available. The selected European cities have a fairly large share of active mobility and public transport in their modal splits. Warsaw, on the other hand, is discussed in the article as an example of a Polish city, whose population is comparable to the analyzed cities.

\section{METHODOLOGY AND PURPOSE OF RESEARCH}

The research is an analysis of theoretical ideas in urban planning and data on city traffic provided by other research and surveys. In the first part the distances described in theoretical papers on shaping of urban units, such as the idea of the "garden city" or the "neighborhood unit", will be presented. Then theories related to the perception of distance not only as a physical dimension, but also as a dimension in space-time, such as the theory of "time budget" will also be described. Subsequently the analysis of the current state of research on walking and cycling distances will be carried up and an attempt to structuralize the results of this research will be made. The results of traffic surveys from several European cities, carried out by city authorities or other public institutions, will then be discussed. In summary, theories regarding distances in the city will be confronted with the results of current research on walking and cycling distances, as well as with data from the aforementioned research and surveys of European cities. The aim of this research is to define what a walking and cycling distance is. Another aim is to describe distances that should be used in urban planning in order to increase the share of walking and cycling (active mobility) in cities. If possible, the dimensions of urban units and kind of facilities that should be found within them will be defined that allow their residents to choose active mobility in their travels as often as possible.

\section{THEORIES ON DISTANCES IN THE CITY}

\subsection{Theories about distance as a dimension in space}

The reflection on distances in the city has been present since the very beginning of urban planning as a science. Ildefonso Cerda, who is considered the father of modern urban planning, designed the expansion of the city of Barcelona in late $19^{\text {th }}$ century. He made sure that all the city's residents have access to numerous basic functions, e.g. to marketplaces which were located evenly so each resident would not have to walk longer than 30 minutes to reach nearest one (Apodaca-Cahalane, 2015). To this day, Barcelona authorities make sure that this accessibility is not only maintained, but even improved (PPS, 2014). Arturo Soria y Mata, another Spanish engineer and the creator of the "linear city" concept, made provisions for specific dimensions for such a city (Boileau, 1959, pp. 230-238). According to his vision urban quarters should be located along the main street with the tram line and they should stretch approximately 200 meters on both sides of it (the entire strip was to be approximately 500 meters wide). Ebenezer Howard also determined specific dimensions 
when describing his idea of the garden city (Howard, 2015, pp. 39). Such a city was intended to be built within the radius of about $1 \mathrm{~km}$ (although it should be remembered that Howard did not assume the garden city to be round in shape). Every inhabitant of the garden city was to reside within this maximum distance from the city center. Access to the local school was to be even easier, as the garden city was to consist of urban units, whose diameter would equal the mentioned $1 \mathrm{~km}$ distance (Fig.2.). Thus, the maximum distance to each school would be around $500 \mathrm{~m}$. Similar assumptions were made by Clarence Perry in his idea of a "neighborhood unit". Such an area was supposed to equal approximately $800 \mathrm{~m}$ in diameter, with a school located in the middle (Byun, Choi \&Choi, 2014). Peter Calthorpe, the creator of the "Transit-Oriented Development" concept, envisaged a similar dimension for urban units. According to his theory, an urban unit should be shaped around stops of efficient public transport (train, metro, bus rapid transit - BRT) and should be of a size that would make it possible for the stop to be reached by walk. Calthorpe assumes $600 \mathrm{~m}$ to be the proper distance (Calthorpe, 1993). The ideal dimensions of an urban unit were also formulated by an urban planner Leon Krier. In his opinion, a urban unit should not be larger than $900 \mathrm{~m}$ in any direction (Krier, 2011, pp. 140). This distance would allow basic needs to be met within a 10-minute walk. Hugh Barton, a British scientist and associate of the World Health Organization (WHO), thinks that different functions in the city may be available at various distances (Barton, Grant \& Guise, 2003)(Fig.1.). The most basic ones, such as a primary school, local shop or park, should be located within the premises of a neighborhood, so that each resident has no more than $1000 \mathrm{~m}$ to reach them. Facilities used less frequently, such as a sports center or specialized stores, etc., as well as workplaces should be located within the district. The resident should dwell no further than $5 \mathrm{~km}$ away from them. However, higher-order services, e.g. a museum or a philharmonic hall, may be placed in the center located further than $5 \mathrm{~km}$ away from the place of residence.

Fig. 1. Diagram showing indicative distances (in meters) from home to a variety of facilities according to Hugh Burton (Barton, Grant \& Guise, 2003) Ryc. 1. Schemat pokazujący orientacyjne odległości ( $w$ metrach) od domu do różnych obiektów według Hugh Burtona (Barton, Grant \& Guise, 2003)

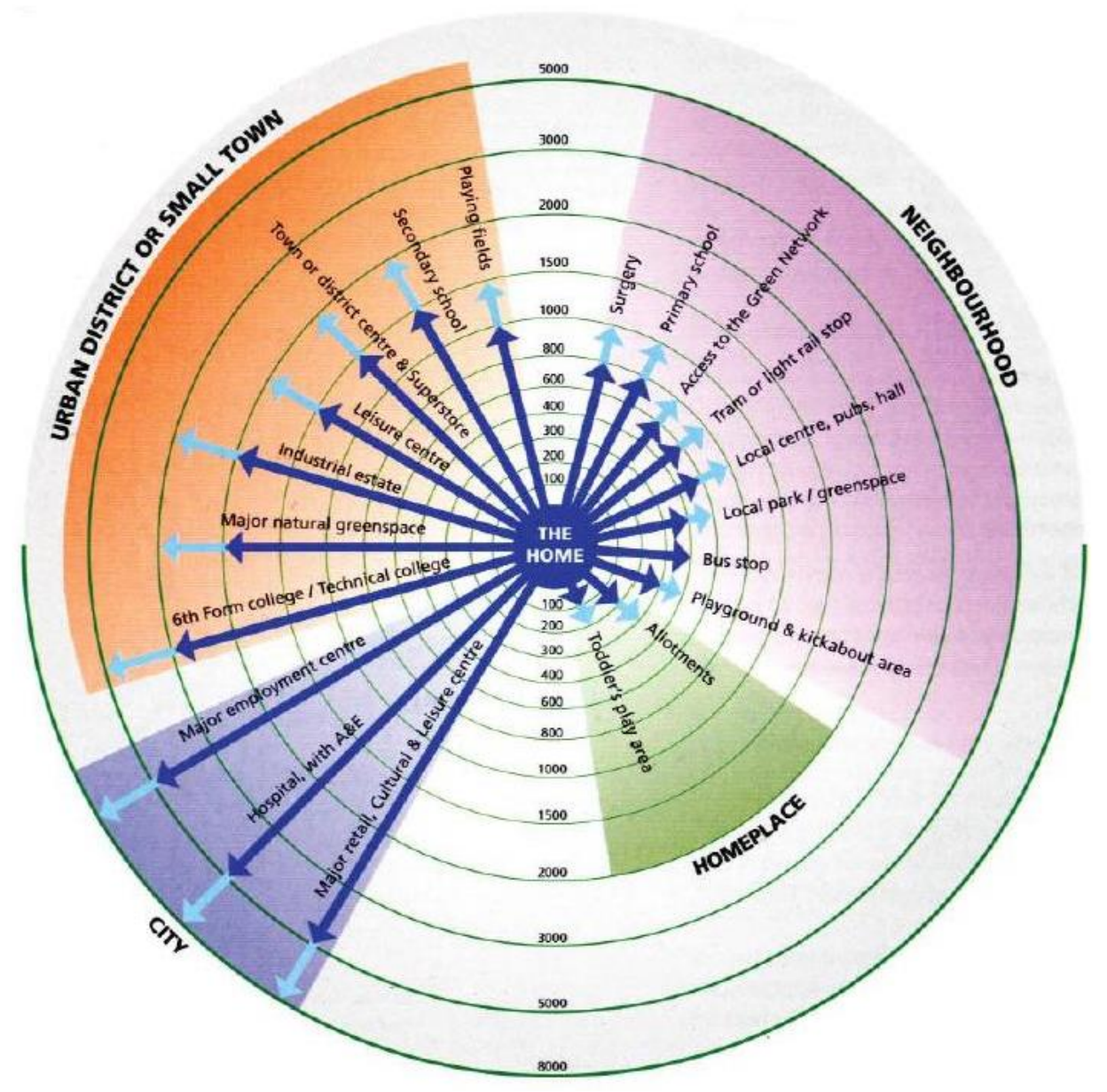




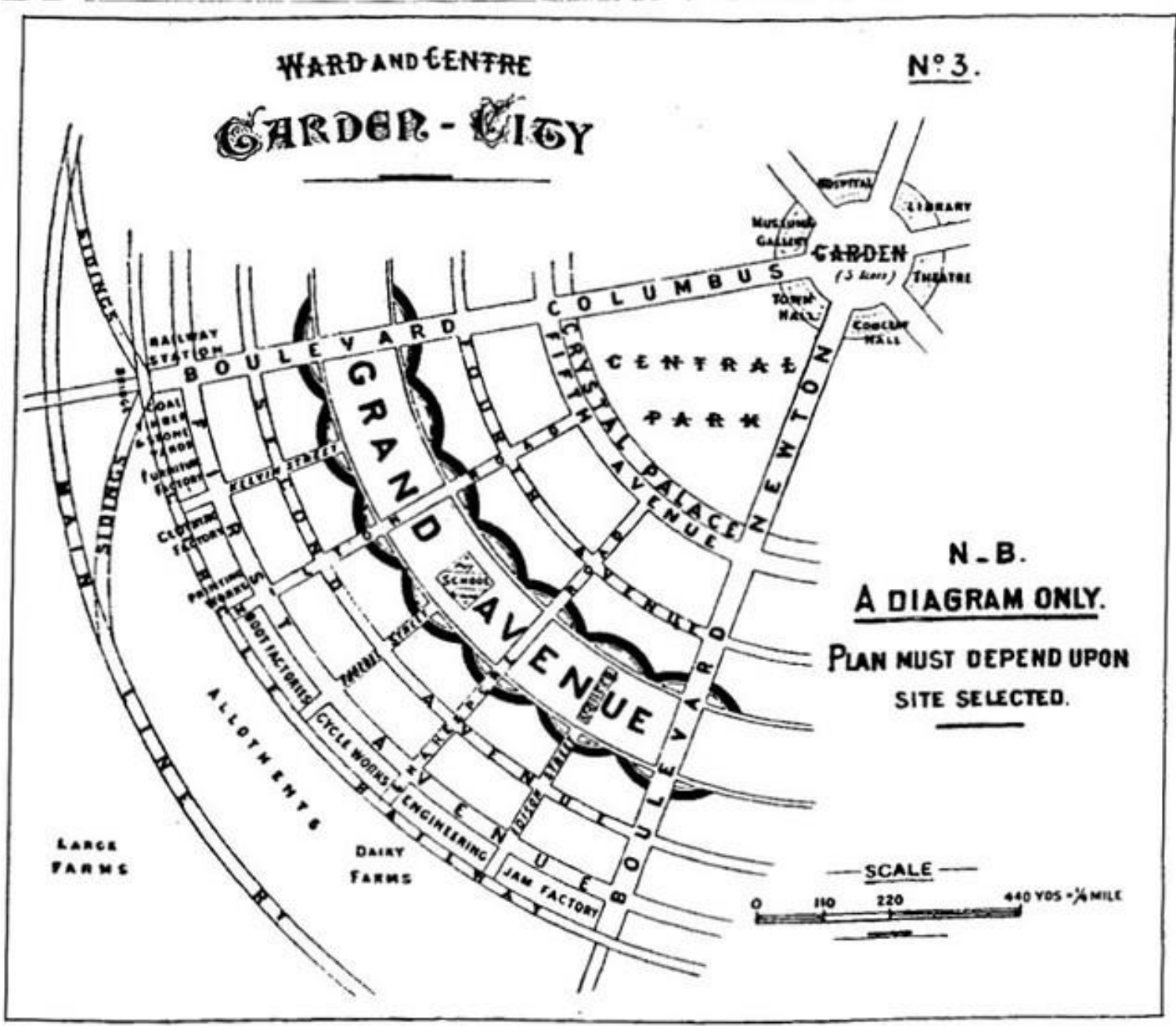

Fig. 2. Diagram showing garden-city concept created by Ebenezer Howard (Howard, 2015)

Ryc. 2. Schemat pokazujący koncepcję miasta-ogrody opracowaną przez Ebenezera Howarda (Howard, 2015)

\subsection{Theories of distance as a dimension in space and time}

Victor Gruen, a Viennese architect, is known as the creator of the first shopping malls, as well as the author of revitalization programs for several American cities downtowns. He was the first to draw attention to another side of walking distance. According to his observations, walking distance should not only be understood as a certain distance in space or amount of time, but rather depends on the environment in which the walk takes place. So, according to Gruen, in an attractively designed environment, protected from the discomfort of adverse weather conditions, people are willing to walk even $1500 \mathrm{~m}$ and spend about 20 minutes doing so. In an attractively designed environment that only provides protection against rain and scorching sun (e.g. arcades) people are willing to go about $760 \mathrm{~m}$ and spend about 10 minutes walking. In an attractive environment that offers no protection from the weather conditions, people are only willing walk about $400 \mathrm{~m}$ and spend about 5 minutes doing it. However, if the surroundings are unattractive and offer no protection against weather conditions, people are only willing to walk $200 \mathrm{~m}$, devoting no more than about 2 minutes to do so (Gruen, 1964, pp. 250). 


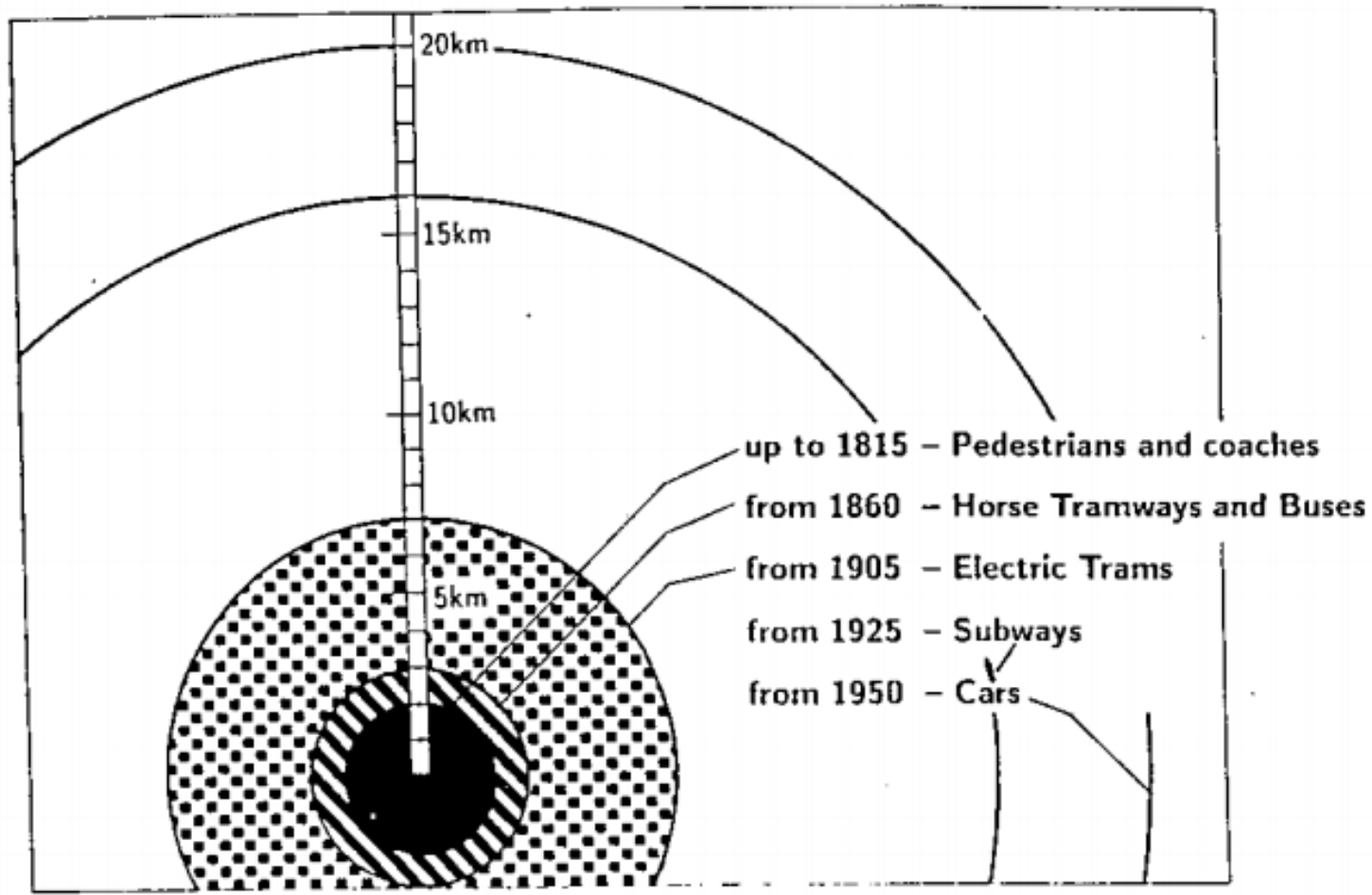

Fig. 3. Diagram showing relation of mean of transport and distance of daily travel according to Cesare Marchetti (Marchetti, 1994)

Ryc. 3. Schemat pokazujący relację środków transportu i dystansu dziennych podróży według Cesare Marchettiego (Marchetti, 1994)

\subsection{Theories of distance as a dimension of time}

The previously described theories were dominated by the definition of distance as a length in space. However, the issue of time should also be taken into account, as in the Gruen's theory. The theory on the relationship between distance and time, the perception of the city in four dimensions as space-time was described by Jakow Zahavi in the 1980s (Zahavi \& Talvitie, 1980, pp. 13-19).. $\mathrm{He}$ analyzed data from cities across different countries, both developed and developing ones, and concluded that the average time devoted to commuting is very similar, namely about an hour. Travel distances, however, vary in space depending on the mode of transport, e.g. people who do not own a car travel approx. $23 \mathrm{~km}$ per day while car owners cover $32-37 \mathrm{~km}$ per day. The main difference lies not in the travel time, but the speed at which the journey is made. Zahavi called this relationship "time budget", each person has to "spend" a day. Obviously, this observation is applied to journeys made in a repetitive manner, rather than those related to tourism or business trips. A decade later, Cesare Marchetti, an Italian physicist decided to investigate whether Zahavi's thesis holds true not only for today's cities, but also for cities in previous epochs (Marchetti, 1994). He compared the dimensions of cities from different historical periods, taking into account the means of transport available in a given period and their speed (Fig.3.). The results showed that the maximum dimensions of ancient cities, such as Rome, and medieval cities, such as Paris, are similar to each other and correspond to the possibility of walking within the time budget described by Zahavi (about an hour per day). Such cities had a diameter of about $5 \mathrm{~km}$ and as the number of inhabitants increased, their population density, rather than the area, increased. It was only the industrial revolution and the accompanying inventions, such as trams and railways, that allowed the territorial expansion of cities. However it was limited by the daily time budget of one hour. The introduction of another invention, namely the car, also allowed an even greater urban growth, which was still within the aforementioned time budget. This phenomenon was called "Marchetti's constant". Carlos Moreno refers to the journey time in his recently famous concept. According to its assumptions, all 
the most basic facilities related to work, study, health, leisure and everyday life should be located within a 15-minute walk (Moreno, 2019). For such time-oriented spatial planning, Moreno coined a new name - chrono-urbanism. Paris is one of the first cities to adopt a strategy for implementing the principles described by Moreno. Other cities, for example Melbourne or Singapore, also include time availability in their strategies, but the limit was set at 20 minutes there. Creating the idea of a 15-minute city, Moreno did not express what distances could define them. This subject has recently been undertaken by Andreas Duany and Robert Steuteville (Duany \& Steuteville, 2021), architects associated with the "New Urbanism" movement. In their article, they refer to the 5-minute walking distance of about $400 \mathrm{~m}$ used in this urban planning concept. In this situation, a 15-minute city should be built in a radius of about $1200 \mathrm{~m}$. The 5 -minute bicycle range, as referred to by the architects, is equal to as about $1600 \mathrm{~m}$, i.e. in the case of bicycle transport, a 15-minute city could be implemented within a radius of even about $4800 \mathrm{~m}$.

\section{WALKING AND CYCLING DISTANCES - CURRENT RESEARCH}

The issue of distances in active mobility is of very complex nature. Such distances depend on the destination, the environment in which the journey is made, as well as the personal characteristics of the traveler, e.g. their gender. In the case of walking distance, a significant variable is whether the trip is made separately, in order to reach the destination directly or whether it is a part of a longer journey, such as reaching a public transport stop.

\subsection{Walking distances in separate walking trips}

In the case of a walking trip independent from other means of transport, the most common distance to be covered equals around 500-800m (Olszewski, 2007; Larsen, El-Geneidy \& Yasmin, 2010). Often the trip distance reaches up to $1-1.5 \mathrm{~km}$ (about $80 \%$ of all cases) (Larsen, El-Geneidy \& Yasmin, 2010). Walking trips are rarely longer than 2-2.5 km (Schaap et al., 2016).. Therefore, three types of walking distances may be distinguished, namely: basic, standard and maximum (Fig. 1.). Moreover, it is worth noting the speed at which pedestrians travel, that is up to about $4-5 \mathrm{~km} / \mathrm{h}$ on average (Olszewski, 2007). This means that the basic walking distance amounts to around 5 minutes, the standard walking distance is up to 10-15 minutes, whereas the maximum walking distance equals around 25-30 minutes. Standard walking distance in time is similar to average walking trip time in the UK which is approximately 16 minutes (Department for Transport, 2019).

\subsection{Walking distances in public transport access trips}

In the case of a walking trip being part of a journey by public transport, differences occur between the means of transport which the pedestrian is trying to reach. People are more likely to travel longer distances to modes of transport that travel at higher speeds and longer distances. Most people tend to reach bus stops located within 300-500m (Daniels \& Mulley, 2013; El-Geneidy et al., 2014). However, the length of access to a railway station is usually $800-1200 \mathrm{~m}$ (Daniels \& Mulley, 2013; El-Geneidy et al., 2014). Research conducted in Sydney has shown that commuters who travel by bus cover the average distance of about $6.5 \mathrm{~km}$ by this means of transport, whereas those who use the train cover about $19 \mathrm{~km}$ by this means (Daniels \& Mulley, 2013). In 2017, Krajowy Instytut Polityki Przestrzennej i Mieszkalnictwa- IPPiM [National Institute for Spatial Policy and Housing] (today Instytut Rozwoju Miast i Regionów [Institute for Urban and Regional Development]) published a report on the pedestrian accessibility of bus, tram and railway stops in Poland. For this study, IPPiM assumed an access distance of $640 \mathrm{~m}$ for bus and tram stops, while $960 \mathrm{~m}$ for railway stops. The assumptions were based on the available literature (IRM, 2017).

\subsection{Walking distances in trips to different destinations}

The destination is of great importance in deciding the distance to be covered. People tend to walk rather shorter distances to reach the local store or school. They tend to cover longer distances to get to work (Larsen, El-Geneidy \& Yasmin, 2010). In general, all facilities related to staying in a given place for longer periods of time or the importance of activity related to a given place extend 
the acceptable walking distance. The shorter the visit to a given facility, the shorter the acceptable walking distance (Schaap et al., 2016). This also applies to travel by public transport. The longer the whole journey, the longer the acceptable distance to reach the stop/station of it. Overall, however, walking trips are quite short, e.g. in the UK (nationwide), walking trips accounts for about $25 \%$ of all journeys, but they only translate into $3 \%$ of the distance covered in total (Department for Transport, 2017).

\subsection{Cycling distances}

Distances covered by bicycle vary to an even greater degree than walking distances. Firstly, a notable aspect, quite constant regardless of the region of the world, is the difference between the distances traveled by men and women, much greater than in the case of walking trips. The average cycling distance is about 3-5 km (Dolati, 2014; Larsen, El-Geneidy \& Yasmin, 2010; Schaap et al., 2016; CyclingUK, 2021), and journeys by bicycle rarely exceed 7-8 km (Schaap et al., 2016) (Fig. 1.). However, on average, men cycle about 1-1.5 km more than women (Dolati, 2014; Schaap et al., 2016). Therefore, when planning bicycle accessibility, the lower part of the scale related to the average length of a bicycle journey should be taken into account, not the upper part. Moreover, noticeable differences exist in the case of the speeds achieved. For example, in the Netherlands the average speed is around $12 \mathrm{~km} / \mathrm{h}$ (Schaap et al., 2016), but in Sweden, it amounts to around $15 \mathrm{~km} / \mathrm{h}$ (Eriksson et al., 2019). However, studies in Sweden, as well as in Italy (Bernardi \& Rupi, 2013), showed quite large variation in the cycling speed, from $12.5 \mathrm{~km} / \mathrm{h}$ to even $26 \mathrm{~km} / \mathrm{h}$. Higher speeds are noted primarily in the areas fitted with a separate bicycle infrastructure, as well as in the case of cyclists who travel longer distances (Schantz, 2017). According to data from Great Britain, a bicycle trip usually takes around 23 minutes in this country (Department for Transport, 2019). It is therefore longer than the walking trip.

\section{DISTANCES IN STUDIES ON THE MOBILITY IN EUROPEAN CITIES}

The authors of urban planning theories make various assumptions, whereas research on distances often requires certain averaging. How does walking and cycling distances look like in practice? The results of surveys on traffic conducted in several European cities are discussed below. Unfortunately, it is not possible to compare the obtained data fully, because various cities use different research methodologies and tend to omit certain issues in their studies, e.g. in Amsterdam and Copenhagen where a high share of bicycle traffic is observed, much less data on pedestrian traffic is gathered. Cities are discussed in alphabetical order below. Warsaw is discussed as the last one for comparison.

\subsection{Amsterdam}

Amsterdam is the first city to be analyzed. It is one of the most "bicycle-oriented" cities in the world. Cycling accounts for about $26 \%$ of all journeys (Gemeente Amsterdam, 2020). A comparable number of journeys are made by car (27\%) and public transport (25\%). Walking has a relatively small share, as it amounts only for $19 \%$ of all journeys. If journeys made by Amsterdam residents only are under consideration, active mobility is even more important. Cycling accounts for $35 \%$ of all journeys, and walking for $24 \%$ of all journeys. On the other hand, the share of motorized means of transport - car and public transport is smaller (both 19\%). Nevertheless, the proportion of walking is quite low. Its higher share can be observed in trips, e.g. for shopping, where almost half (48\%) of journeys is made on foot, the share of cycling in such trips (30\%) is average against the entire city. This low proportion of walking could probably be explained by the fact that cycling is competitive to walking, especially over longer distances. Amsterdam also boasts a higher share of cycling in the inner districts. In districts located within the A10 by-pass, which is located about $4 \mathrm{~km}$ away from the city center (Fig.4.), the share of cycling in modal split with walking excluded (in Amsterdam, not much data is gathered on walking) is around $50-60 \%$. In the same area, the share of public transport is $20-24 \%$. In central districts, the observed speed of bicycle users reaches about 15-17 $\mathrm{km} / \mathrm{h}$. In the outskirts, the speed may be even as high as $30 \mathrm{~km} / \mathrm{h}$. However, in the very center, the speed can drop to as low as $10 \mathrm{~km} / \mathrm{h}$. In the surveys ankietowych (Nello-Deakin \& Nikolaeva, 
2020), bicycle users explain this with the increased pedestrian traffic in the city center. This fact is noteworthy, as walking and cycling are often considered jointly as "active mobility", but it should be made clear that in certain cases these types of traffic compete with each other. Amsterdam authorities do not collect data on travel distances and time spans. Such research is carried out independently of the city authorities and shows that the average distance traveled by bike in Amsterdam is about $2 \mathrm{~km}$ (Ton et al., 2017). There are also nationwide research (Ton $\mathrm{i}$ in., 2019), which shows that the average walking trip lasts 10 minutes and takes place over a distance of $700 \mathrm{~m}$, the average bicycle journey takes 13 minutes and takes place over a distance of $3 \mathrm{~km}$, whereas the average journey by public transport takes 66 minutes. and takes place over a distance of $40 \mathrm{~km}$. However, in the case of walking trips, the Dutch Institute for Transport Policy Analysis provides slightly different data, which show that the average journey by foot is $1.5 \mathrm{~km}$, and for a distance of up to $2.5 \mathrm{~km}$, the share of walking and cycling is similar and amounts to $37-39 \%$ (de Haas \& Hamersma, 2019).

\subsection{Berlin}

Berlin - the capital of Germany - is a much larger city than Amsterdam (Fig.4.), but it as well has a very high share of active mobility in modal split (Senatsverwaltung für Umwelt, Verkehr und Klimaschutz, 2019). In this case, however, walking predominates, as it accounts for $30 \%$ of all journeys. Cycling accounts for $18 \%$ of all journeys, whereas public transport for $27 \%$ of the total number of journeys. It is worth noting that active mobility refers mostly to short-distance journeys. Only $5 \%$ of the distance of all journeys is made on foot, while $12 \%$ of the total by bicycle. Public transport accounts for $42 \%$ of combined distance of all journeys. Berliners are most likely to made walking trips while going to the shops (39\% of trips), leisure activities $(37 \%)$ and education facilities (29\%). The opposite is true for cycling. $23 \%$ of trips are to education facilities, $17 \%$ to leisure facilities and $13 \%$ of shopping trips are made by bicycle. Berliners tend to reach work by public transport (40\%), $20 \%$ commute by bicycle and $11 \%$ walk. At the same time, the longest distances are covered when commuting to work, an average of $10.5 \mathrm{~km}$. Berliners cover of an average $4.1 \mathrm{~km}$ to education facilities, $5.2 \mathrm{~km}$ to places of leisure, whereas $3.5 \mathrm{~km}$ to reach a shop. Study from Berlin contains also data of modal split for different distances. A distance of up to $1 \mathrm{~km}$ is dominated by walking $(77 \%)$, followed by cycling (15\%). At a distance of $1-3 \mathrm{~km}$, cycling $(30 \%)$ takes the lead over walking (26\%). At a distance of $3-5 \mathrm{~km}$, walking is negligible (5\%), but cycling still accounts for $24 \%$ of all journeys. At a distance of more than $5 \mathrm{~km}$, practically no walking is observed, while up to $10 \mathrm{~km}$, cycling still accounts for $18 \%$ of journeys. Above $10 \mathrm{~km}$, bicycle traffic is negligible. "Active mobility" is the dominant mode of transport for distances up to $1 \mathrm{~km}(92 \%)$ and $3-5 \mathrm{~km}(56 \%)$. In Berlin, the average journey (for all means of transport) amount to approximately 6 $\mathrm{km}$ and takes an average of 24 minutes. In the case of walking, the average distance is $0.9 \mathrm{~km}$ and 14 minutes, the average journey by bicycle equals $2.4 \mathrm{~km}$ and 19 minutes, whereas on public transport, the average journey is $8.7 \mathrm{~km}$ and 40.5 minutes. The Berlin study also shows that there is a difference in the acceptable access to stops of different types of public transport. Berliners usually spend up to 5 minutes to get to the bus stop, and up to 10-15 minutes to get to the tram, rail or metro stop or station.

\subsection{Copenhagen}

Like Amsterdam, Copenhagen - the capital of Denmark - is a very "bicycle-oriented" city. Copenhagen as well as Amsterdam collect little official data on walking. Of all journeys in 2017, those made by bicycle accounted for $29 \%$, i.e. comparable to Amsterdam. The share of walking was also similar to that observed in Amsterdam and that mode of transport accounted for $18 \%$ of journeys \% (City of Copenhagen, 2017). The share of public transport was lower and amounted to 18\%. Moreover, the observed speed of bicyclists is similar to that recorded in Amsterdam and amounts to about $15-16 \mathrm{~km} / \mathrm{h}$ (City of Copenhagen, 2011). It should be noted that the presented data was gathered for the administrative city of Copenhagen, which area roughly corresponds to the central districts of Amsterdam (Fig.4.). Its borders are within a radius of about $5 \mathrm{~km}$ from the city center. In Copenhagen, walking has the highest share at distances of up to $2 \mathrm{~km}(43 \%)$. However, even at this distance, it is less popular than cycling (50\%). At a distance of $2-5 \mathrm{~km}$, walking is negligible 
$(6 \%)$, whereas cycling is definitely dominant $(64 \%)$. Cycling remains a frequent means of transport

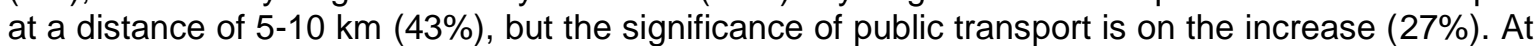
the distance of $10-15 \mathrm{~km}$, motorized forms of transportation prevail, e.g. public transport (rail, metro, bus - 32\%), although cycling stands at $18 \%$ (City of Copenhagen, 2011). In Copenhagen, "active mobility" dominates over a slightly longer distance than in Berlin, that is up to $5 \mathrm{~km}$. Survey conducted by the authorities of the Capital Region (Capital Region of Denmark, 2017) shed light on traffic situation in the remaining parts of the agglomeration. Overall, cycling in the region accounts for about $20 \%$ of all trips. In Copenhagen and Frederiksberg ${ }^{1}$ alone, cycling accounts for $33 \%$ of all trips, while bicycle journeys in the suburbs of Copenhagen account for $17 \%$ of all trips. Cycling distance of up to $2 \mathrm{~km}$ stands for $25-30 \%$ of all trips in the region. At the distance of $2-5 \mathrm{~km}, 30$ $35 \%$ of the total of journeys is made by bicycle. At the distance of $5-10 \mathrm{~km}$, the figure equals 20 $25 \%$, over $10 \mathrm{~km}$, bicycle trips stand at $5-10 \%$ of all trips in the region. The average distance covered by bicycle in the region is up to $2 \mathrm{~km}$. Both in Copenhagen and in the region, bicycle journeys prevail at the distance of up to $5 \mathrm{~km}$. At distances of over $10 \mathrm{~km}$, the use of such transportation is negligible.

\subsection{London}

London presents relatively little data relating to walking and cycling in the scope of issues covered in the this article. Across London, walking accounts for $25 \%$ of all journeys. The share of cycling is the lowest of all previously described cities, in 2017 it amounted only to 2\% (Transport for London, 2018). The share of public transport in the entire city was $37 \%$. As was the case of previously discussed cities, these indicators are more favorable for "active mobility" in the central districts that make up the so-called Inner London. The area is located within a radius of about $8 \mathrm{~km}$ from London city center, while the boundaries of London extend $20-25 \mathrm{~km}$ from the city center (Fig.4.). In Inner London, $36 \%$ of journeys are made on foot, while the share of cycling is twice as high as across the city as a whole, it stands at $4 \%$. It is also within this part of the city and in the districts along the River Thames to the west of the city center where the highest share of journeys by bicycle are observed (ONS, 2014). The same observation applies to walking (Department for Transport, 2019). The share of public transport in Inner London is similar to that across the entire city and amounts to $38 \%$ (Transport for London, 2018). Unfortunately, reports on the Transport for London, do not provide information on the travel time span and distances covered by each means. Only data from the network of city bike rentals is available, according to which the average bike rental lasts $13-25$ minutes.

\subsection{Paris}

Paris, the capital of France, is more successful in terms of "active mobility". Here, even at the level of the lle-de-France region agglomeration, walking accounts for a significant share of all journeys, as it stands at $39 \%$ (DRIEA, 2013). This makes walking the most popular means of transport in the entire agglomeration. The bicycle is rarely used in Paris region, as only $1.5 \%$ of all journeys are made by it. In Paris alone, "active mobility" accounts for as much as $55 \%$ of all journeys, whereas in certain districts it amounts to as much as $60 \%$. As in the previously discussed cities, walking dominates, as it accounts for $52 \%$ of all journeys. As in the case of London, the share of cycling in the center of Paris agglomeration is twice as high as the average for the entire agglomeration. It is worth noting that the size of administrative city of Paris is comparable to the size of administrative city of Copenhagen or Amsterdam (Fig.4.) within the A10 by-pass road and the radius from the center to the city borders equals about $5 \mathrm{~km}$. On the scale of the entire agglomeration, public transport accounts for around $20 \%$ of journeys, whereas in Paris alone it stands at $32 \%$ of all journeys. As in the case of Berlin, walking is most important when traveling to education facilities $(55 \%$ of journeys) and shopping (57\%), as well as for accompanying/escorting (46\% of journeys). Very few Parisians walk to work ( $10 \%$ of journeys). For this type of journey, the cycling is more common. The inhabitants of Paris cover relatively short distances. The average walking distance is about $400 \mathrm{~m}$ and it is similar both in the city and in the agglomeration as a whole. The average time span

\footnotetext{
${ }^{1}$ Frederiksberg is an independent city that is an enclave on the territory of city of Copenhagen.
} 
of a walking trip is 12 minutes and it is also similar within the city itself and across the entire agglomeration. However, there is a difference in the distances associated with different destinations. Parisians usually cover a distance of about 300 meters to educational facilities and for shopping. On the other hand, they are willing to walk over twice as far in order to reach leisure facilities. Also in the case of cycling, no big difference between the city and the agglomeration as a whole is observed. In both cases, the average distance of a bicycle trip reaches about $2 \mathrm{~km}$, while the average time amounts to 19 minutes. On the other hand, significant differences between the city and the agglomeration are visible in the distance covered by public transport. In Paris, the average distance is $5.3 \mathrm{~km}$, whereas in the agglomeration as a whole, it is $9 \mathrm{~km}$. However, the difference is smaller in the case of the average journey time. Within the city, the average journey by public transport takes 38 minutes, while within the agglomeration - 48 minutes. This divergence probably results from the use of different means of transport. Paris has a fairly dense metro network with stops within a very short distance. The entire agglomeration is served by a regional railway network which stops are less frequent. Therefore, the speed of railway traffic can be higher. For comparison, the average distance of all trips in the agglomeration is $4.4 \mathrm{~km}$, whereas the average time is 24 minutes.

\subsection{Vienna}

Like Paris, Vienna is definitely a pedestrian city. Walking accounts for $28 \%$ of all journeys (Stadtentwicklung und Stadtplanung Wien, 2015). Like in Paris or London, bicycle traffic is relatively low, but still accounts for $6 \%$ of all journeys. $38 \%$ of journeys are made by public transport. Similarly to Paris or London, differences may be seen between the average for the city as a whole and for its central districts, i.e. the part of the city from early modern period bordered by the Gürtel bypass (radius $2.5 \mathrm{~km}$ from the center)(Fig.4.). In these districts, the average share of walking reaches $33 \%(20-40 \%$ in particular districts), while the share of cycling traffic stands at $9 \%(3-15 \%$ in particular districts). It is worth noting, however, that bicycle traffic is rather low $(3 \%)$ in the old town itself, where there are many pedestrian zones. Public transport in all districts accounts around $40 \%$ of all journeys. As in the case of Berlin and Paris, Viennese mainly walk to shop (51\% of journeys in the case of basic purchases and 34\% of journeys in the case of other purchases) and to education facilities (26\% of journeys). A large share of walking is also noticed while covering distances to entertainment facilities (gastronomy, culture - 31\%) and sports and leisure facilities (24\%). However, walking trips are quite short. On average walking journeys covers a distance of $0.8 \mathrm{~km}$. Walking accounts for $99 \%$ of journeys up to $500 \mathrm{~m}$ and $77 \%$ of journeys at distances of $500-1000 \mathrm{~m}$. For a distance of $1-2 \mathrm{~km}$, walking trips account for $32 \%$ of journeys, while for a distance of $2-3 \mathrm{~km}, 14 \%$ of all journeys. Walking is very rare over longer distances. Overall, almost $80 \%$ of all walking journeys are made at distances of up to $1 \mathrm{~km}$. Cycling trips are slightly longer, $2.8 \mathrm{~km}$ long on average. Cycling journeys accounts for $1 \%$ of all journeys taking place at distances up to $500 \mathrm{~m}$, $8 \%$ of journeys at $500-1000 \mathrm{~m}$, and $15 \%$ of journeys at $1-2 \mathrm{~km}$. Over this distance, the share of bicycle trips declines. Bicycle journeys account for $9 \%$ of all trips over a distance of $2-3 \mathrm{~km}, 6 \%$ for a distance of $3-5 \mathrm{~km}$, and $7 \%$ for a distance of 7-8 km. Longer journeys by this means are now quite rare. Overall, $80 \%$ of all bicycle journeys cover distances of up to $5 \mathrm{~km}$. The average distance traveled by public transport is $5.6 \mathrm{~km}$, and the average distance of all journeys in the city is $4 \mathrm{~km}$. In terms of travel time, the average walking trip in Vienna equals 18 minutes, and $80 \%$ walking journeys take no more than 20 minutes. The average bicycle trip is 21 minutes and $75 \%$ of bicycle trips are within 20 minutes. The average journey by public transport takes 37 minutes, while $73 \%$ of journeys by public transport are within 40 minutes.

\subsection{Warsaw}

Warsaw was included in the study mainly for comparison (Fig.4.). The share of "active mobility" in all journeys stands at $21 \%$. Most of these trips are walking trips and their account for $18 \%$ of all trips. It is a similar share to the one in Amsterdam or Copenhagen, but in those cities the cycling is an important means of transport. In Warsaw, bicycle transport accounts for only $3 \%$ of all journeys. It is worth to mention that at the beginning of the 1990s, walking share in Warsaw reached about $30 \%$ (BPMiT, 2016). It has since declined in favor of car transport. Most likely, the formerly high share resulted mainly from the lack of access to car transport, rather than from preferences of the 
inhabitants. The share of public transport in Warsaw is quite high and amounts to $47 \%$. Detailed data on walking are not gathered in Warsaw. Warszawskie Badanie Ruchu (WBR) [Warsaw Traffic Survey] reports only that most of the walking trips to work are made at a distance of up to $2.5 \mathrm{~km}$, while the highest share (about 60\%) is observed at distances up to $1 \mathrm{~km}$. Trips to education facilities are slightly longer, even up to $3 \mathrm{~km}$, but most of them (about $80 \%$ ) still take place at a distance of up to $1 \mathrm{~km}$. Moreover, WBR provides data on some distances without assigning them a means of transport. As in other cities, journeys for basic shopping and services as well as to places of entertainment are quite short. More than $40 \%$ of them take place at distances of up to $1 \mathrm{~km}$, whereas over $70 \%$ at distances of up to $3 \mathrm{~km}$. Trips to work are longer and usually take 5-8 km. Overall, a walking journey in Warsaw takes an average of 14 minutes, and $76 \%$ of walking journeys are within 15 minutes. The average bicycle trip is 25 minutes and $78 \%$ of bicycle trips are within 30 minutes. The average journey by public transport takes 41 minutes, while $68 \%$ of public transport journeys are within 45 minutes.

Fig. 4. Plans of described cities. Borders of cities and their agglomeration are shown. Distances from center are superimposed on maps (author's own work based on maps from OpenStreetMap.org) Ryc. 4. Plany opisywanych miast. Przedstawiono granice miast i ich aglomeracje. Odległości od centrum są nakładane na mapy (praca własna autora na podstawie map z OpenStreetMap.org)
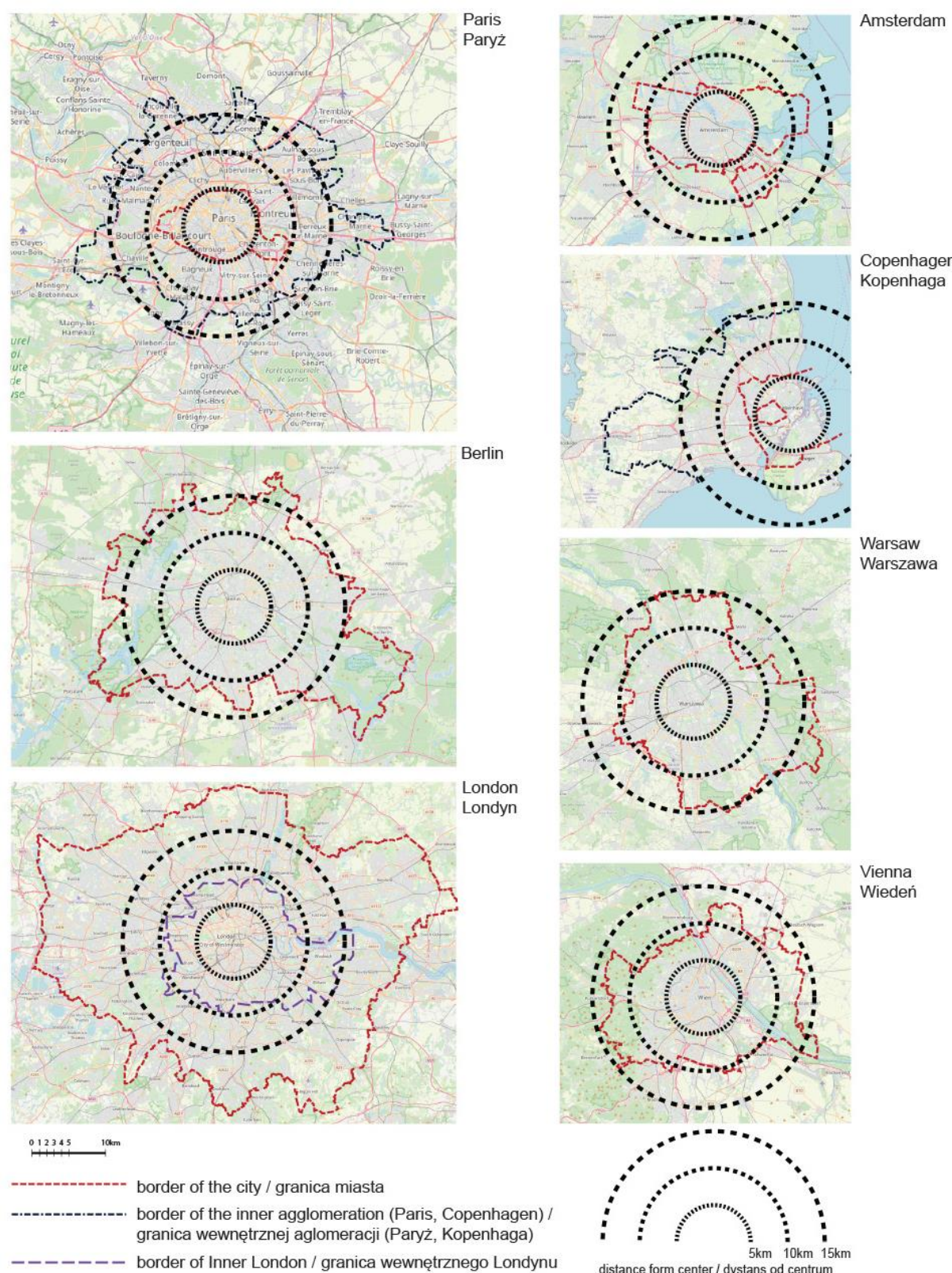

distance form center / dystans od centrum 


\section{SUMMARY AND CONCLUSIONS}

\subsection{Conclusions on walking}

A comparison of studies on distances in the city with surveys on mobility in European cities confirms that walking trips most often take place at distances of up to $400-900 \mathrm{~m}$ (Fig. 5.), although figures differ in various cities. An obstacle to determining the walking distance more accurately lies in the variety of methods used for measuring traffic in different cities. For example, the Copenhagen study, where the shortest distance analyzed is $2 \mathrm{~km}$, does not provide data needed to assess the walking distance in that city. On the other hand, collected data confirm that the maximum walking distance stands at about 2-3 km (Fig. 5.). Moreover, the walking trip time span is similar everywhere and amounts to about 15 minutes. Analysis confirms the usefulness of dividing walking distances into basic, standard and maximum, which often are also associated with diverse travel destinations, e.g. the basic distance is related to getting to school, while the standard distance is related to reaching the place of work or leisure facilities. Paris offers an interesting case study, as an average journey length of around $400 \mathrm{~m}$ takes the average time of 12 minutes there. This would mean that Parisians walk twice slower than the standard speed $4-5 \mathrm{~km} / \mathrm{h}$. This may be influenced by a large share of walking trips to school (children walk more slowly). Perhaps there are also barriers in the city (e.g. long waiting at traffic lights), which slow down the pedestrians. This shows that when planning a city for pedestrians, more factors than just distance need to be considered. It is also interesting to observe that there is a low share of walking trips in cities with a high number of bicycle trips. This outcome proves that while walking and cycling are classified together as 'active mobility', they are in competition with each other in certain cases. This applies to both competing for the choice of a given means of transport and competition for space, as shown by the example of old towns in Amsterdam and Vienna.

\subsection{Conclusions on cycling}

The analysis of data on cycling allows to determine a distance of up to $2 \mathrm{~km}$, which can be called the basic distance (Fig. 5.), where cycling often competes with pedestrian traffic. In addition, the analysis confirmed that bicycle trips very often cover a distance of 3-5 km (Fig. 5.), which can be called a standard bicycle distance (it is worth noting that some analyzed cities have administrative boundaries within a radius of $5 \mathrm{~km}$ from the center). The maximum distance usually stands at around 7-10 km (Fig. 5.). Longer journeys are more often made by the inhabitants of the Copenhagen agglomeration, which can probably be associated with the developed bicycle infrastructure. It is also interesting that while walking trips to work are quite rare, cycling is in competition with public and car transport for this type of commute. Cycling journeys tend to be longer than walking journeys and last on average about 20 minutes. The average cycling speed in the city should be assumed around $15-16 \mathrm{~km} / \mathrm{h}$. In parts of the city with higher share of pedestrian traffic, this speed is rather closer to $10 \mathrm{~km} / \mathrm{h}$, whereas in areas further away from the city center, it may exceed $20 \mathrm{~km} / \mathrm{h}$.

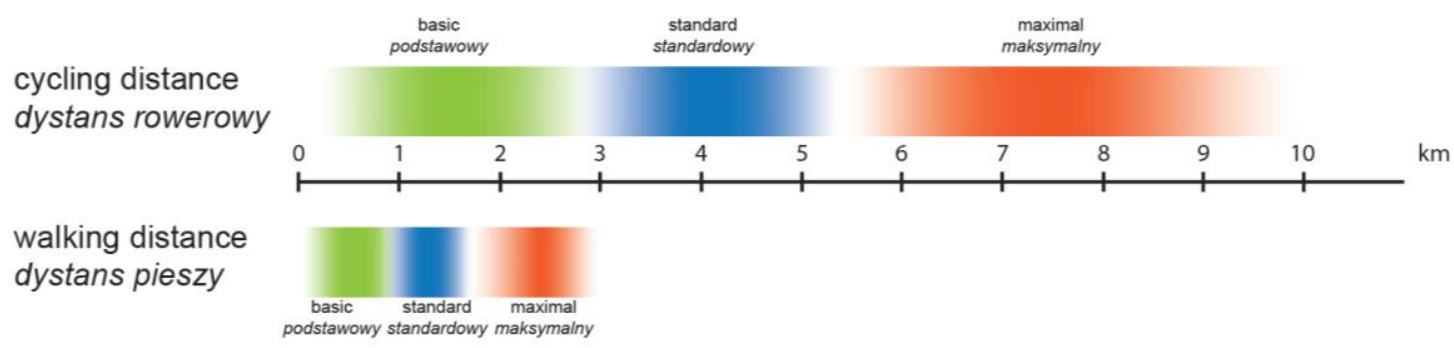

Fig. 5. Summary of bicycle and pedestrian distances

Ryc. 5. Zestawienie dystansów rowerowych i pieszych 


\subsection{Conclusions on public transport}

Public transport varies greatly across analyzed cities. Its common feature, however, is a longer distance traveled with the use of its means, often $10 \mathrm{~km}$ and over, as well as a longer journey time span, often 40 minutes and more. Perhaps this could explain the higher share of public transport in larger cities and agglomerations such as Berlin, Vienna or the Paris agglomeration. Studies from European cities also confirm that the tendency to walk longer to reach a given means of transport stop depends on its type.

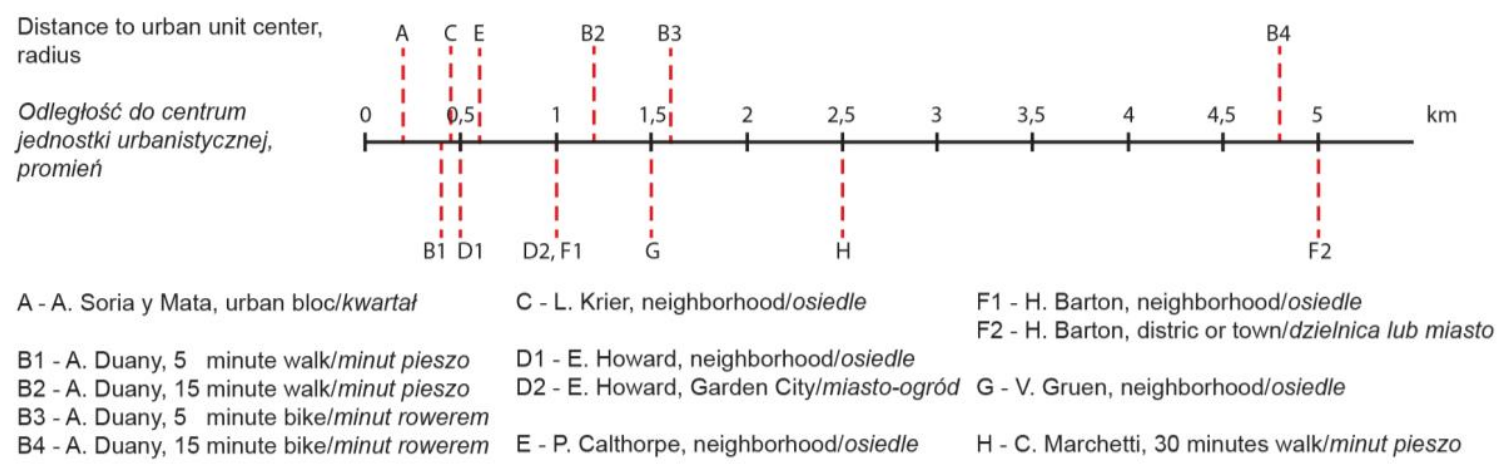

Fig. 6. Summary of distances from urban theories

Ryc. 6. Zestawienie dystansów z teorii urbanistycznych

\subsection{Conclusions regarding the dimensions of urban units}

Comparing distances covered by walking and cycling to the dimensions of urban units from various theoretical projects (Fig. 6.), it must be admitted that city dimensions were most accurately proposed by Ebenezer Howard, whose garden city is within the maximum walking distance and the basic bicycle distance. The dimensions of a "neighborhood unit" proposed by Clarence Perry and urban unit dimensions proposed by Leon Krier also suit well the results of distances analysis. In both cases, they are within the standard walking distance. Urban units proposed by Victor Gruen also lie within the standard walking distance (Fig. 5.), both in terms of length and time span. Arturo Soria y Mata in the "linear city" project and Peter Calthorpe in the concept of "Transit Oriented Development" (TOD) were very "frugal " in the assumed distances. The "linear city" could be twice as wide and would still remain within the standard walking distance (in terms of width of the city). On the other hand, the TOD urban unit has the same dimensions, regardless of the means of transport that serve it, while the distance to reach e.g. a railway station could be several hundred meters longer. The distances to Barcelona's markets proposed by Ildefons Cerda are rather outdated. Perhaps 100 years ago, people were willing to spend 30 minutes or more to reach fairly basic functions. Today they would rather travel such a distance by bicycle, but for sure some would choose motorized transport. The idea of "time budget" proposed by Yacov Zahavi is only partially confirmed. People are willing to spend less time on "active mobility" journeys than on motorized travel. "Active" journeys usually takes about 20 minutes, while motorized one could be twice as long. This result partially undermines the "Marchetti constant". It is true for the historical description of urban development, since even nowadays districts of cities such as Paris and Vienna located within a 30minute walk from the center, have a higher share of "active mobility". In practice, however, people spend more time walking or cycling only when they have no other choice or treat it as a leisure activity. The "Marchetti constant" thus determines the maximum walking distance, but cannot be used as a simple model for designing the size of urban units. This does not mean, however, that taking into account the dimension of time in spatial planning is irrelevant. Quite the opposite is true. It is the travel time, rather than travel length, in different cities that shows greater convergence. Therefore, it is sensible to further develop the idea of "chronourbanism" proposed by Carlos Moreno. The concept is much more demanding to urban planners, because it is not based on simple 
distance in space guidelines, but needs to be adapted to the time span the city dweller is willing to spend on walking it. It is also impossible to adopt a constant speed for a given means of transport, e.g. walking or cycling, because it differs between city areas and also depends on who the user is. It can also be discussed whether the 15 minutes proposed by Moreno is enough. The assumptions of Singapore or Melbourne, where the idea of a "20-minute city" is developed are probably more realistic. However, translating this into real space dimensions, studies from European cities suggest that the dimensions of a "15-minute district" with a radius of around 1200m that can be extended up to $1500 \mathrm{~m}$, proposed by Andreas Duany and Robert Steuteville, can be considered quite correct. In addition, they remain within the standard walking distance. However, dimensions of the "bicycle city" adopted by them seem risky, as they are based on the assumption that bicycle users move at speeds of $20 \mathrm{~km} / \mathrm{h}$. European studies show that the average speed is rather around $15 \mathrm{~km} / \mathrm{h}$, and for short journeys (Duany and Steuteville describe 5-minute journeys) the speed may be lower, closer to $10 \mathrm{~km} / \mathrm{h}$. In such a case 5-minute bike trip is about $800-1200 \mathrm{~m}$, and a 10minute trip is $1.6-2.5 \mathrm{~km}$. On the other hand, since bicycle trips are usually longer, and the bicycle is more often used, for example, as a means of transport to work, perhaps a 15- or 20-minute city should comprise diverse "layers" - walking and cycling with different destinations available by different means of transport. In this way, it seems that a 15-minute or 20-minute city is very well connected with the concept of distances proposed by Hugh Barton. He differentiates distances depending on the destination by dividing the city into a neighborhood with dimensions corresponding to the standard walking distance (distances up to $1000 \mathrm{~m}$ ) and a district/town with dimensions of a standard bicycle distance (distances up to $5 \mathrm{~km}$ ). Public transport should probably be introduced to support more specialized destinations.

The analysis of the theories and data from European cities described in the article leads to the conclusion that access to various facilities in a city should be linked to the means of transport used to reach a given facilities. Basic facilities such as kindergarten, elementary school, primary health care, and convenience stores and basic recreational activities, such as a playground or sports field, should be as close as possible to where people live. Ideally, they should be at a distance not greater than the basic walking distance, i.e. $800-900 \mathrm{~m}$ (Fig.5.). This should be the scale of the neighborhood, preferably not crossed by any street with heavy traffic. Less often visited facilities, such as clothing stores, as well as large recreational areas (swimming pools, sports clubs), but also entertainment (e.g. cinema), culture and gastronomy may be located at a greater distance. However, it should not exceed 3-5 km, which corresponds to the basic cycling distance and the maximum walking distance (about $3 \mathrm{~km}$ ) and the standard bicycle distance (about $5 \mathrm{~km}$ ) (Fig.5.). The distance of 3-5 km is the size of the district, which enables people living in it to meet most of the their needs without the need to use mechanized transport. Facilities rarely visited, such as specialist stores or places of higher culture (philharmonics, museums), and above all, workplaces can be located much further, best up to $10 \mathrm{~km}$ or even more from the place of residence. However, in their case, travel time is much more important than the distance itself, and that distance may be different for different modes of transport. The time for such a trip should not exceed 40-50 minutes. This is most important for the daily commuting. Therefore, it should not be expected that a lot of people will walk to work. If the inhabitants will use any means of active mobility when traveling to work, it would rather be a bicycle. In general, it should be assumed that active mobility will dominate short journeys up to $2-3 \mathrm{~km}$. With a larger share of bicycle transport, journeys can be longer and even exceed $5 \mathrm{~km}$. However, it must be assumed that from these $2-3 \mathrm{~km}$ the share of mechanized transport will increase. It is best if it will be public transport. For this to happen, however, it is necessary to properly connect the public transport network with the city structure. First of all, the distance to railway, metro and tram stops should not be greater than the basic pedestrian distance, for buses that distance should be cut in half. The workplaces themselves and other non-local facilities should be located in places easily accessible from different parts of the city by public transport. Interestingly, Berlin seems to be such a "model city", with its polycentric structure, where almost half of the journeys are related to "active mobility", whereas a large share of the remaining journeys are made using public transport. As it may be seen, even a very large city can function as a city of short distances. It is important to be aware of the fact that "short distance" may be understood in a number of ways. 


\title{
DYSTANSE MIEJSKIE. WYMIARY JEDNOSTEK URBANISTYCZNYCH ORAZ ROZMIESZCZENIE FUNKCJI W MIEŚCIE W KONTEKŚCIE DYSTANSÓW PIESZYCH, ROWEROWYCH I TRANSPORTU PUBLICZNEGO
}

\begin{abstract}
1.WSTĘP
Transport jest jednym z najważniejszych elementów planowania przestrzennego, ale z drugiej strony to planowanie przestrzenne ma bardzo istotny wpływ na transport. To czy mieszkańcy częściej wybierają zrównoważone formy transportu takie jak chodzenie piechotą, jazda na rowerze czy transport zbiorowy, a nie indywidualny transport samochodowy często wynika nie tylko z dostępności infrastruktury przeznaczonej dla danego środka transportu, ale także z dystansów między terenami i obiektami o funkcjach, których mieszkańcy potrzebują. Nie da się zatem zmieniać miejskiej mobilności na bardziej przyjazną środowisku i zdrowiu tylko rozbudowując linie transportu zbiorowego czy budując drogi rowerowe. Podstawowym zdaniem powinno być takie przekształcenie struktury miejskiej by odpowiadała ona dystansom, które ludzie zazwyczaj pokonują na piechotę, na rowerze czy transportem zbiorowym. Przy tym większą uwagę należy zwrócić na różne formy aktywnej mobilności (ruch pieszy i rowerowy) niż na nieco przeceniany w krajach dawnego bloku wschodniego transport zbiorowy. W niniejszym artykule zostaną przeanalizowane teorie dotyczące dystansów w mieście od czasów Ebenezera Howarda do współczesnej teorii „miasta 15 minut”. Teorie te zostaną następnie skonfrontowane $z$ danymi z badań ruchu przeprowadzonych przez władze Amsterdamu, Berlina, Kopenhagi, Londynu, Paryża, Warszawy oraz Wiednia. W miarę dostępności danych zostanie pokazane nie tylko jaki jest średni dystans w odległości i/lub w czasie dla różnych form transportu, ale także preferencje związane z obiektami i terenami o poszczególnych funkcjach. Dobrane miasta europejskie mają dość duży udział aktywnej mobilności i transportu zbiorowego w liczbie podróży. Natomiast Warszawa została dodana jako przykład polskiego miasta o zbliżonej do pozostałych liczbie ludności.
\end{abstract}

\section{METODOLOGIA I CEL BADAŃ}

Badania mają charakter analizy źródeł. W pierwszej kolejności zostaną przedstawione dystanse opisane w pracach teoretycznych dotyczących kształtowania jednostek urbanistycznych takich jak np. idea "miasta-ogrodu” czy jednostki sąsiedzkiej. Zostaną także opisane teorie związane z postrzeganiem dystansu nie tylko jako odległości, ale jako wymiaru w czasoprzestrzeni jak np. teoria dotycząca „budżetu czasowego". Następnie zostanie przeanalizowany istniejący stan badań naukowych nad dystansami pieszymi i rowerowymi oraz zostanie podjęta próba ustrukturalizowania wyników tych badań. Następnie zostaną omówione wyniki badań ruchu z kilku europejskich miast prowadzonych przez władze tych miast lub inne instytucje publiczne. W podsumowaniu teorie dotyczące dystansów w mieście zostaną skonfrontowane $z$ wynikami współczesnych badań nad dystansami pieszymi i rowerowymi, a także $z$ danymi $z$ badań $z$ wymienionych wcześniej europejskich miast. Celem badań jest odpowiedź na pytanie czym w zasadzie jest dystans pieszy i rowerowy i jakie odległości należy dla nich przyjmować w projektowaniu urbanistycznym by zwiększać udział ruchu pieszego i rowerowego (aktywnej mobilności) w miastach. W miarę możliwości zostanie także wskazane jakie powinny być wymiary jednostek urbanistycznych i jakie funkcje powinny w nich się znaleźć by mieszkańcy jak najczęściej wybierali aktywną mobilność w swoich podróżach.

\section{TEORIE DOTYCZĄCE DYSTANSÓW W MIEŚCIE}

\subsection{Teorie dotyczące dystansu jako odległości}

Namysł nad dystansami w mieście był obecny od samego początku urbanistyki jako nauki. Już sam twórca tego terminu Ildefons Cerda projektując rozbudowę Barcelony zadbał o to by mieszkańcy mieli dostęp do wielu podstawowych funkcji np. do targowisk, które zostały tak zlokalizowa- 
ne by żaden mieszkaniec nie miał do takiego targowiska dalej niż 30 minut drogi (ApodacaCahalane, 2015). Barcelona do dziś dba o to by ta dostępność nie tylko została zachowana, ale wręcz poprawiła się (PPS, 2014). Również inny hiszpański inżynier Arturo Soria y Mata, twórca idei „miasta liniowego” przewidział dla niego konkretne wymiary (Boileau, 1959, s. 230-238). Położone wzdłuż głównej ulicy z linią tramwajową kwartały miały być sięgać mniej więcej $200 \mathrm{~m}$ po obu jej stronach (całe pasmo miało mieć około 500m szerokości). Także Ebenezer Howard opisując swoją ideę miasta-ogrodu podaje konkretne wymiary (Howard, 2015, s. 39). Miasto takie miało mieć promień około $1 \mathrm{~km}$ (choć należy pamiętać, że Howard nie zakładał, że miasto-ogród ma być okrągłe). W takiej maksymalnej odległości od centrum miasta mieszkałby każdy mieszkaniec miasta-ogrodu. Dostęp do lokalnej szkoły byłby jeszcze łatwiejszy, gdyż miasto ogród miało się składać z osiedli, dla których ten $1 \mathrm{~km}$ byłby średnicą (Ryc. 2.). Zatem maksymalna odległość do każdej szkoły wynosiłaby około $500 \mathrm{~m}$. Podobne założenia pojawiły się w opisanej przez Clarence'a Perry'ego idei „jednostki sąsiedzkiej”. Miała ona mieć średnicę zbliżoną do $800 \mathrm{~m}$ ze szkołą zlokalizowaną w środku (Byun, Choi i Choi, 2014). Również Peter Calthorpe - twórca idei „Transit Oriented Development" przewidywał zbliżony wymiar dla osiedla. Według jego teorii powinno ono być kształtowane wokół przystanków wydajnego transportu zbiorowego (kolej, metro, szybki autobus) i powinno mieć taką wielkość by dało się do tego przystanku dojść pieszo. Calthorpe za taką odległość przyjmuje $600 \mathrm{~m}$ (Calthorpe, 1993). Idealne wymiary osiedla sformułował też w swojej koncepcji urbanista Leon Krier. Jego zdaniem w żadną stronę nie powinno być ono większe niż 900m (Krier, 2011 , s. 140). To miałoby pozwolić na zaspokajanie podstawowych potrzeb w zasięgu 10minutowego marszu. Natomiast brytyjski naukowiec, współpracownik Światowej Organizacji Zdrowia (WHO) Hugh Barton wskazuje, że w mieście różne funkcje mogą być dostępne w różnych odległościach (Barton, Grant i Guise, 2003)(Ryc.1.). Te najbardziej podstawowe jak np. szkoła podstawowa, lokalny sklep czy park powinny znajdować się w obrębie osiedla tak by każdy mieszkaniec miał do nich nie dalej niż $1000 \mathrm{~m}$. Usługi, z których korzysta się rzadziej, takie jak np. centrum sportowe czy sklepy specjalistyczne itp., a także miejsca pracy powinny znaleźć się na terenie dzielnicy, gdzie mieszkaniec nie powinien do nich mieć dalej niż $5 \mathrm{~km}$. Natomiast usługi wyższego rzędu np. muzeum czy filharmonia mogą znajdować się w centrum oddalonym dalej niż $5 \mathrm{~km}$.

\subsection{Teorie dotyczące dystansu jako odległości i czasu}

$\mathrm{Na}$ inną stronę dystansu pieszego zwrócił uwagę twórca pierwszych centrów handlowych, a także projektów rewitalizacji centrów amerykańskich miast, pochodzący z Wiednia architekt Victor Gruen. Z jego obserwacji wynikało, że dystans pieszy nie jest tylko i wyłącznie pewną odległością czy ilością czasu, ale jest także zależny od otoczenia, w którym ruch pieszy się odbywa. Tak więc zdaniem Gruena w otoczeniu atrakcyjnie zaprojektowanym i chronionym przed dyskomfortem warunków atmosferycznych ludzie są skłonni przejść nawet 1500m i poświęcić na to około 20 minut. $\mathrm{W}$ otoczeniu atrakcyjnie zaprojektowanym, ale chroniącym tylko przed deszczem i upalnym słońcem (np. podcienia) ludzie są skłonni przejść około $760 \mathrm{~m}$ i poświęcić na to około 10 minut. W otoczeniu, które jest atrakcyjne, ale w żaden sposób nie chroni przed warunkami atmosferycznymi ludzie są skłonni przejść około $400 \mathrm{~m}$ poświęcając na to około 5 minut. Natomiast, jeśli otoczenie nie tylko nie chroni przed warunkami atmosferycznymi, ale także jest nieatrakcyjnie ludzie skłonni są przejść tylko $200 \mathrm{~m}$ poświęcając na to około 2 minut (Gruen, 1964, s. 250).

\subsection{Teorie dotyczące dystansu jako czasu}

W opisanych wcześniej teoriach dominuje pojęcie dystansu jako odległości w przestrzeni. Jednak podobnie jak to zrobił Gruen trzeba zwrócić uwagę także na czas. Teorię dotyczącą powiązania dystansu z czasem, a więc spojrzenia na miasto w czterech wymiarach jako czasoprzestrzeni przedstawił w latach 80-tych XX wieku Yacov Zahavi (Zahavi i Talvitie, 1980, s. 13-19). Przeanalizował on dane z miast $z$ różnych krajów, zarówno rozwiniętych jak i rozwijających się i doszedł do wniosku, że średni czas, który ich mieszkańcy poświęcają na podróże w ciągu jest bardzo podobny i wynosi około jednej godziny. Różnią się jednak dystanse w przestrzeni w zależności od środka transportu np. osoby nie posiadające własnego samochodu pokonują dziennie ok. $23 \mathrm{~km}$, a posiadające samochód 32-37km dziennie. Podstawową różnicą nie jest czas przeznaczony na podróże, ale prędkość z jaką odbywa się podróż. Zahavi określił tę zależność mianem „budżetu czasowego”, 
który każda osoba ma codziennie do „wydania”. Obserwacja ta dotyczy oczywiście podróży powtarzalnych, a nie takich związanych z turystyką lub podróży służbowych. Dekadę później włoski fizyk Cesare Marchetii postanowił zbadać czy postawiona przez Zahaviego teza sprawdza się nie tylko dla miast teraźniejszych, ale także dla miast w poprzednich epokach (Marchetii, 1994). Porównał zatem wymiary miast $z$ różnych okresów historycznych biorąc pod uwagę dostępne w danym okresie środki transportu i ich prędkość (Ryc. 3.). Okazało się, że rzeczywiście maksymalne wymiary miast z czasów starożytnych np. Rzymu jak i średniowiecza np. Paryża są do siebie podobne i odpowiadają możliwości pieszego dojścia w budżecie czasowym opisanym przez Zahaviego (około godziny dziennie). Miasta takie miały średnicę około $5 \mathrm{~km}$ i wraz ze wzrostem liczby mieszkańców rosła raczej ich gęstość zaludnienia, a nie powierzchnia. Dopiero rewolucja przemysłowa i towarzyszące jej wynalazki takie jak tramwaj i kolej pozwoliły na ekspansję terytorialną miast cały czas ograniczoną jednak dziennym budżetem czasowym jednej godziny. Wprowadzenie kolejnego wynalazku - samochodu również pozwoliło na jeszcze większy rozrost miast, który nadal mieści się we wspomnianym budżecie czasowym. Fenomen ten nosi nazwę „stałej Marchettiego”. Do czasu podróży odnosi się w swojej głośnej ostatnio koncepcji Carlos Moreno. Według jego założeń wszystkie najbardziej potrzebne miejsca związane z pracą, nauką, zdrowiem wypoczynkiem i codziennym życiem powinny znajdować się w zasięgu 15 minut marszu (Moreno, 2019). Dla takiego uwzględniającego czas planowania przestrzennego Moreno wprowadził nawet nową nazwę - chronourbanizm. Jednym z pierwszych miast, które przyjęło strategię wdrażania opisanych przez Moreno zasad jest Paryż (Guardian, 2020). Inne np. Melbourne (State Government of Victoria, 2016) czy Singapur (Land Transport Authority) również wpisują w swoje strategie dostępność czasową, ale tam za wartość graniczną przyjęto 20 minut. Tworząc ideę miasta 15-minutowego Moreno nie zdefiniował jakie odległości mogłyby je wyznaczać. Temat ten podjęli ostatnio architekci związani z ruchem "Nowego Urbanizmu” - Andreas Duany i Robert Steuteville (Duany i Steuteville, 2021). W swoim artykule przywołują oni stosowany w tej szkole urbanistyki zasięg pieszy 5-minutowy o wymiarze około $400 \mathrm{~m}$. W tej sytuacji miasto 15 -minutowe powinno być zbudowane tak by mieściło się w promieniu około $1200 \mathrm{~m}$. Przywoływany przez nich 5-minutowy zasięg rowerowy wynosi około $1600 \mathrm{~m}$, czyli w przypadku transportu rowerowego miasto 15-minutowe mogłoby mieć promień nawet około $4800 \mathrm{~m}$.

\section{DYSTANSE PIESZE I ROWEROWE - STAN BADAŃ}

Zagadnienie dystansów w aktywnej mobilności jest bardzo złożone są one zależne od celu podróży, otoczenia, w którym podróż się odbywa, a także cech osobniczych osoby podróżującej np. jej płci. W przypadku dystansu pieszego jedną $z$ istotnych cech jest to czy jest to osobna podróż bezpośrednio do celu czy też element dłuższej podróży - dojście do przystanku transportu zbiorowego.

\subsection{Dystanse piesze w samodzielnych podróżach pieszych}

W przypadku podróży pieszej bez wykorzystania innych środków transportu najczęstszy dystans wynosi około 500-800m (Olszewski, 2007; Larsen, El-Geneidy i Yasmin, 2010). Dość częste (około $80 \%$ wszystkich podróży) są także podróże do 1-1,5km (Larsen, El-Geneidy i Yasmin, 2010). Odległość, którą piesi rzadko przekraczają to natomiast 2-2,5km (Schaap i in., 2016). Można zatem powiedzieć, że mamy trzy rodzaje dystansów w podróżach pieszych - podstawowy, zasadniczy i maksymalny. Warto pamiętać o prędkości, z którą poruszają się piesi, średnio to około $4-5 \mathrm{~km} / \mathrm{h}$ (Olszewski, 2007). Oznacza to, że podstawowy dystans pieszy to około 5 minut, zasadniczy dystans pieszy to 10-15 minut, a maksymalny dystans pieszy to około 25-30 minut. Dla przykładu w Wielkiej Brytanii średnia podróż piesza trwa około 16 minut (Department for Transport, 2019).

\subsection{Dystanse piesze w podróży pieszej będącej dojściem do innego środka transportu}

W przypadku podróży pieszej będącej częścią podróży transportem zbiorowym występują różnice pomiędzy środkami transportu, do których pieszy zmierza. Ludzie są bardziej skłonni do pokonania dłuższych dystansów do tych środków transportu, którymi podróżują z większą prędkością i na większe odległości. Na przystanek autobusu większość osób dociera z odległości 300-500m (Da- 
niels i Mulley, 2013; El-Geneidy i in., 2014). Natomiast długość dojścia na przystanek kolei wynosi zazwyczaj 800-1200m (Daniels i Mulley, 2013; El-Geneidy i in., 2014). Badania prowadzone w Sydney pokazały, że korzystający później z autobusu pokonują nim średnio około $6,5 \mathrm{~km}$, a korzystający z kolej około 19km (Daniels, Mulley, 2013). W roku 2017 roku Krajowego Instytutu Polityki Przestrzennej i Mieszkalnictwa (dziś Instytut Rozwoju Miast i Regionów) opublikował raport dotyczący dostępności pieszej przystanków autobusowych i tramwajowych oraz kolejowych w Polsce. Do badania tego KIPPiM przyjął odległości $640 \mathrm{~m}$ dla przystanków autobusowych i tramwajowych oraz $960 \mathrm{~m}$ dla przystanków kolejowych opierając te założenia na dostępnej literaturze (IRM, 2017).

\subsection{Dystanse piesze w podróżach do różnych celów}

W decyzjach dotyczących dystansu dojścia duże znaczenie odgrywa cel podróży. Ludzie są skłonni pokonywać raczej krótsze odległości do sklepu czy szkoły. Dojście do pracy może być dłuższe (Larsen, El-Geneidy i Yasmin, 2010). Ogólnie wszystkie funkcje, które są związane z dłuższym przebywaniem $w$ danym miejscu lub ważnością aktywności związanej $z$ danym miejscem wydłużają akceptowalny dystans dojścia. Im krótsza wizyta w danej funkcji tym krótszy akceptowalny dystans dojścia (Schaap i in., 2016). To samo dotyczy podróży z wykorzystaniem transportu zbiorowego. Im dłuższa cała podróż tym dłuższy akceptowalny dystans dojścia. Ogólnie jednak podróże piesze są dość krótkie np. w Wielkiej Brytanii (w całym kraju) stanowią około 25\% wszystkich podróży, ale odpowiadają tylko za 3\% odległości wszystkich podróży (Department for Transport, 2017).

\subsection{Dystanse rowerowe}

Dystanse rowerowe są jeszcze bardziej zróżnicowane niż dystanse piesze. Pierwszym co rzuca się w oczy i jest dość stałe niezależnie od rejonu świata jest znacznie większe niż w przypadku podróży pieszych zróżnicowanie w pokonywanych dystansach pomiędzy mężczyznami i kobietami. Średni dystans rowerowy to około 3-5km (Dolati, 2014; Larsen, El-Geneidy i Yasmin, 2010; Schaap i in., 2016; CyclingUK, 2021), a podróże rowerowe rzadko przekraczają 7-8km (Schaap i in., 2016). Jednak średnio mężczyźni przejeżdżają około 1-1,5km więcej niż kobiety (Dolati, 2014; Schaap i in., 2016). Dlatego planując dostępność rowerową należy brać pod uwagę raczej dolną, a nie górną część skali związanej ze średnią długością podróży rowerowej. Także w przypadku osiąganych prędkości dostrzegalne są różnice. Na przykład w Holandii średnia prędkość to około $12 \mathrm{~km} / \mathrm{h}$ (Schaap i in., 2016), ale już np. w Szwecji to około 15km/h (Eriksson i in., 2019). Jednak w badaniach w tym kraju, a także we Włoszech (Bernardi i Rupi, 2013) notowano dość duże zróżnicowanie prędkości rowerzystów od $12,5 \mathrm{~km} / \mathrm{h}$ do nawet $26 \mathrm{~km} / \mathrm{h}$. Wyższe prędkości są notowane przede wszystkim tam gdzie występuje wydzielona infrastruktura rowerowa, a także w przypadku osób, które podróżują na większe odległości (Schantz, 2017). Według danych z Wielkiej Brytanii podróż rowerowa w tym kraju trwa zazwyczaj około 23 minut (Department for Transport, 2019). Jest zatem dłuższa niż podróż piesza.

\section{DYSTANSE W BADANIACH RUCHU EUROPEJSKICH MIAST}

Autorzy teorii urbanistycznych przyjmują różne założenia, a badania nad dystansami często wymagają pewnego uśrednienia. Jak jednak wyglądają dystanse piesze i rowerowe w praktyce? Poniżej zostaną omówione wyniki badań ruchu z kilku europejskich miast. Niestety nie jest możliwe pełne ich porównanie, ponieważ różne miasta stosują różną metodologię badań, a także nie badają niektórych zagadnień np. Amsterdam i Kopenhaga - miasta o dużym udziale ruchu rowerowego zbierają znacznie mniej danych na temat ruchu pieszego. Miasta będą omawiane w kolejności alfabetycznej. Warszawa zostanie omówiona na końcu dla porównania.

\subsection{Amsterdam}

Pierwszym analizowanym miastem jest Amsterdam. To jedno z najbardziej „rowerowych” miast świata. Podróże rowerem stanowią tu około $26 \%$ wszystkich (Gemeente Amsterdam, 2020). Po- 
równywalna liczba podróży odbywa się z wykorzystaniem samochodu (27\%) oraz transportu publicznego (25\%). Dość niewielki udział ma ruch pieszy, gdyż jest to tylko 19\%. Jeśli uwzględnić tylko podróże mieszkańców Amsterdamu to aktywna mobilność jest jeszcze ważniejsza. Ruch rowerowy odpowiada z 35\% podróży, a pieszy za 24\%. Mniejszy jest natomiast udział transportu zmechanizowanego - samochodowego i transportu publicznego (oba po 19\%). Niemniej udział ruchu pieszego jest dość niski. Wyższy jego udział można zaobserwować w podróżach np. na zakupy gdzie prawie połowa (48\%) podróży jest piesza, udział ruchu rowerowego (30\%) jest przeciętny na tle całego miasta. Ten niski udział ruchu pieszego można prawdopodobnie tłumaczyć tym,, że ruch rowerowy stanowi konkurencję dla ruchu pieszego, zwłaszcza na dłuższych dystansach. W Amsterdamie można także zaobserwować wyższy udział ruchu rowerowego w centralnej części miasta. W dzielnicach położonych wewnątrz obwodnicy A10 oddalonej od centrum o mniej więcej 4km (Ryc. 4.) udział ruchu rowerowego wśród podróży nie pieszych (Amsterdam nie zbiera wielu danych dotyczących ruchu pieszego) wynosi około 50-60\%. Na tym samym obszarze udział transportu zbiorowego to $20-24 \%$. W dzielnicach centralnych obserwowana prędkość użytkowników rowerów to około $15-17 \mathrm{~km} / \mathrm{h}$. W dzielnicach obrzeżnych to nawet $30 \mathrm{~km} / \mathrm{h}$. Natomiast w samym centrum prędkość może spaść nawet do $10 \mathrm{~km} / \mathrm{h}$. W badaniach ankietowych (Nello-Deakin i Nikolaeva, 2020) użytkownicy rowerów tłumaczą to nasilonym ruchem pieszych w centrum. Warto to odnotować, gdyż ruch pieszy i rowerowy często jest traktowany wspólnie jako „aktywna mobilność", ale należy mieć świadomość, że w określonych przypadkach są to rodzaje ruchu stanowiące dla siebie konkurencję. Władze Amsterdamu nie zbierają danych o dystansach i czasie podróży. Badania takie są prowadzone niezależnie od władz miasta i wynika z nich, że średni dystans pokonywany na rowerze w Amsterdamie wynosi około $2 \mathrm{~km}$ (Ton i in., 2017). Są także ogólnokrajowe badania z Holandii (Ton i in., 2019), z których wynika, że średnia podróż piesza trwa 10 minut i odbywa się na dystansie $700 \mathrm{~m}$, średnia podróż rowerowa trwa 13 minut i odbywa się na dystansie $3 \mathrm{~km}$, a średnia podróż transportem publicznym trwa 66 minut i odbywa się na dystansie $40 \mathrm{~km}$. Jednak w przypadku ruchu pieszego Niderlandzki Instytut Analiz Polityki Transportowej podaje trochę inne dane, z których wynika, że średnia podróż piesza odbywa się na dystansie 1,5km, a na dystansie do 2,5km udział podróży pieszych i rowerowych jest podobny i wynosi 37-39\% (de Haas i Hamersma, 2019).

\subsection{Berlin}

Stolica Niemiec - Berlin jest znacznie większym miastem niż Amsterdam (Ryc. 4.), ale również ma bardzo duży udział aktywnej mobilności w podróżach (Senatsverwaltung für Umwelt, Verkehr und Klimaschutz, 2019). Tutaj jednak dominuje ruch pieszy, który stanowi 30\% wszystkich podróży. Ruch rowerowy odpowiada za $18 \%$ wszystkich podróży, a transport publiczny za $27 \%$. Warto jednak zwrócić uwagę, że aktywna mobilność to podróże na krótkie dystanse. Pieszo jest pokonywanych zaledwie $5 \%$ odległości wszystkich podróży, a rowerem $12 \%$. Transport publiczny odpowiada za $42 \%$ długości wszystkich podróży. Pieszo Berlińczycy najczęściej chodzą do sklepu (39\% podróży), a dalszej kolejności do miejsc spędzania czasu wolnego (37\%) i do miejsc nauki (29\%). W przypadku ruchu rowerowego jest dokładnie na odwrót. Rowerem odbywa się 23\% podróży do miejsc nauki, $17 \%$ do miejsc spędzania czasu wolnego, a $13 \%$ do sklepu. Do pracy Berlińczycy najczęściej docierają transportem zbiorowym (40\%), 20\% dojeżdża rowerem, a 11\% przychodzi pieszo. Jednocześnie to do pracy pokonywane są największe odległości, średnio 10,5km. Do miejsc nauki Berlińczycy pokonują średnio $4,1 \mathrm{~km}$, do miejsc spędzania czasu wolnego 5,2km, a do sklepu 3,5km. Jeśli chodzi o poszczególne dystanse to na dystansie do $1 \mathrm{~km}$ zdecydowanie dominuje ruch pieszy $(77 \%)$, a następnie rowerowy (15\%). Na dystansie $1-3 \mathrm{~km}$ ruch rowerowy $(30 \%)$ wyprzedza ruch pieszy (26\%). Na dystansie 3-5km ruch pieszy jest już znikomy (5\%), ale ruch rowerowy nadal stanowi $24 \%$ wszystkich podróży. Na dystansie powyżej $5 \mathrm{~km}$ już praktycznie nie ma ruchu pieszego natomiast do $10 \mathrm{~km}$ udział ruchu rowerowego nadal stanowi $18 \%$ podróży. Powyżej 10km ruch rowerowy jest już znikomy. „Aktywna mobilność” jest dominującym środkiem transportu na dystansach do $1 \mathrm{~km}(92 \%)$ i 3-5km (56\%). W Berlinie średnia podróż (dla wszystkich środków transportu) odbywa się na dystansie około $6 \mathrm{~km}$ i trwa średnio 24 minuty. W przypadku ruchu pieszego średnia podróż to dystans $0,9 \mathrm{~km}$ i 14 minut, średnia podróż rowerem to 2,4km i 19 minut, a w transporcie zbiorowym średnia podróż to $8,7 \mathrm{~km}$ i 40,5 minuty. Berlińskie badanie pokazuje także, że jest różnica w akceptowalnym dojściu do przystanków różnych typów transportu 
publicznego. Na dojście do przystanku autobusu mieszkańcy Berlina zazwyczaj przeznaczają do 5 minut, a na dojście to przystanku tramwaju, kolei lub metra są w stanie poświęcić nawet 10-15 minut.

\subsection{Kopenhaga}

Stolica Danii - Kopenhaga to podobnie jak Amsterdam bardzo „rowerowe miasto”. Podobnie z resztą jak w Amsterdamie jego władze nie zbieraj wielu danych dotyczących ruchu pieszego. Spośród wszystkich podróży te wykonywane rowerem stanowiły w 2017 roku 29\%, czyli porównywalnie z Amsterdamem. Również udział ruchu pieszego był podobny na poziomie $18 \%$ (City of Copenhagen, 2017). Niższy był udział transportu publicznego i wyniósł on $18 \%$. Również obserwowana prędkość użytkowników rowerów jest podobna jak w Amsterdamie i wynosi około 15$16 \mathrm{~km} / \mathrm{h}$ (City of Copenhagen, 2011). Należy przy tym zaznaczyć, że są to dane dla administracyjnego miasta Kopenhagi, która w przybliżeniu odpowiada centralnym dzielnicom Amsterdamu. Jej granice znajdują się w promieniu około $5 \mathrm{~km}$ od centrum miasta (Ryc. 4.). W Kopenhadze ruch pieszy ma najwyższy udział wśród wszystkich podróży na dystansie do $2 \mathrm{~km}(43 \%)$. Jednak nawet na tym dystansie przewyższa go ruch rowerowy $(50 \%)$. Na dystansie $2-5 \mathrm{~km}$ ruch pieszy jest już znikomy $(6 \%)$, a zdecydowanie dominuje ruch rowerowy (64\%). Na dystansie $5-10 \mathrm{~km}$ nadal istotny jest ruch rowerowy $(43 \%)$, ale coraz większą rolę odgrywa transport publiczny $(27 \%)$. Na dystansie $10-15 \mathrm{~km}$ zaczynają dominować zmechanizowane formy transportu np. transport publiczny (kolej, metro, autobus $-32 \%$ ), choć ruch rowerowy jeszcze utrzymuje się na poziomie $18 \%$ (City of Copenhagen, 2011). W Kopenhadze „aktywna mobilność” dominuje na trochę większym dystansie niż w Berlinie do $5 \mathrm{~km}$. Badania prowadzone przez władze Regionu Stołecznego (Capital Region of Denmark, 2017) pozwalają poznać sytuację także w pozostałej części aglomeracji. Ogólnie w regionie podróże rowerowe stanowią około $20 \%$ wszystkich podróży. Podróże rowerowe tylko w Kopenhadze i Frederiksbergu ${ }^{2}$ to $33 \%$ wszystkich podróży, a podróże rowerowe na przedmieściach Kopenhagi to $17 \%$ wszystkich podróży. Na dystansie do $2 \mathrm{~km}$ podróże rowerowe stanowią $25-30 \%$ wszystkich podróży w regionie. Na dystansie $2-5 \mathrm{~km}$ to $30-35 \%$, na dystansie $5-10 \mathrm{~km}$ to $20-25 \%$, a powyżej $10 \mathrm{~km}$ podróże rowerowe to $5-10 \%$ wszystkich podróży w regionie. Średnia długość podróży rowerowej $w$ regionie to $2 \mathrm{~km}$. Widać, że zarówno w Kopenhadze jak i w regionie podróże rowerowe stanowią większość na dystansie do $5 \mathrm{~km}$. Natomiast stają się znikome na dystansie powyżej $10 \mathrm{~km}$.

\subsection{Londyn}

Londyn prezentuje dość niewiele danych związanych z ruchem pieszym i rowerowym dotyczących kwestii opisywanych w tym artykule. W całym Londynie udział ruchu pieszego we wszystkich podróżach to $25 \%$. Udział ruchu rowerowego jest najniższy z dotychczas opisanych miast i w 2017 roku wynosił zaledwie 2\% (Transport for London, 2018). Udział transportu publicznego w skali całego miasta wynosił natomiast $37 \%$. Podobnie jak w innych miastach te wskaźniki są bardziej korzystne dla „aktywnej mobilności” w dzielnicach centralnych tworzących tak zwany Londyn Wewnętrzny (Inner London). Zawierają się one w promieniu około $8 \mathrm{~km}$ od centrum podczas gdy granice Londynu sięgają 20-25km od centrum (Ryc. 4.). W Londynie Wewnętrznym pieszo pokonywanych jest $36 \%$ podróży, a udział ruchu rowerowego jest dwukrotnie większy niż w całym mieście i wynosi $4 \%$. To również w obrębie tej części miasta oraz w dzielnicach wzdłuż Tamizy na zachód od centrum obserwuje się najwięcej podróży rowerowych (ONS, 2014). Podobnie jest z resztą z ruchem pieszym (Department for Transport, 2019). Udział transportu zbiorowego w Londynie Wewnętrznym jest podobny jak w całym mieście i wynosi 38\% (Transport for London, 2018). Raporty Transport for London nie zawierają niestety informacji o czasie podróży oraz pokonywanych dystansach. Podane są jedynie dane z sieci wypożyczalni rowerów miejskich, w których przeciętne wypożyczenie roweru trwa 13-25 minut.

\footnotetext{
${ }^{2}$ Frederiksberg to niezależne miasto stanowiące enklawę na terenie Kopenhagi.
} 


\subsection{Paryż}

Znacznie lepiej pod względem „aktywnej mobilności” prezentuje się stolica Francji - Paryż. Tutaj nawet na poziomie aglomeracji regionu lle-de-France ruch pieszy ma znaczący udział we wszystkich podróżach, który wynosi 39\% (DRIEA, 2013). To czyni ruch pieszy najpopularniejszym środkiem transportu w całej aglomeracji. Rower jest rzadko używany w aglomeracji paryskiej. Tylko $1,5 \%$ podróży odbywa się przy jego udziale. W samym Paryżu „aktywna mobilność” to aż 55\% wszystkich podróży, a w niektórych dzielnicach nawet $60 \%$. Tutaj też dominuje ruch pieszy, który odpowiada za 52\% podróży. Podobnie jak w Londynie w centrum aglomeracji ruch rowerowy jest dwukrotnie większy niż średnia dla całej aglomeracji. Warto przy tym zauważyć, że administracyjny Paryż jest wielkością porównywalny jest z administracyjną Kopenhagą czy Amsterdamem w obrębie obwodnicy A10 i promień od centrum do granic miasta wynosi około $5 \mathrm{~km}$ (Ryc.4.). Transport publiczny w skali aglomeracji odpowiada za około $20 \%$ podróży, a w samym Paryżu za $32 \%$ podróży. Podobnie jak w Berlinie ruch pieszy ma największe znaczenie w podróżach do miejsc nauki (55\% podróży) oraz na zakupy (57\%), a także w przypadku odprowadzania/odwożenia (46\% podróży). Bardzo mało Paryżan chodzi pieszo do pracy (10\% podróży). W tego typu podróżach ważniejszy jest rower. Mieszkańcy Paryża pokonują stosunkowo krótkie dystanse. Średni dystans pieszy to około $400 \mathrm{~m}$ i jest on podobny zarówno w samym mieście jak i w aglomeracji. Średni czas podróży pieszej to 12 minut i również jest on podobny w samym mieście jak i w całej aglomeracji. Jest jednak różnica w dystansach związanych z różnymi miejscami docelowymi. Do miejsca nauki oraz do sklepu Paryżanie pokonują zazwyczaj dystans około 300m. Natomiast do miejsc spędzania wolnego czasu są już skłonni chodzić ponad dwukrotnie dalej. Także w przypadku ruchu rowerowego nie widać większej różnicy między miastem i aglomeracją. W obu przypadkach średni dystans podroży rowerowej to około $2 \mathrm{~km}$, a średni czas to 19 minut. Znaczne różnice między miastem a aglomeracją są natomiast widoczne w dystansie pokonywanym transportem publicznym. W Paryżu średni dystans to $5,3 \mathrm{~km}$, a w aglomeracji to już $9 \mathrm{~km}$. Różnica ta jest jednak mniejsza w przypadku średniego czasu podróży. W obrębie miasta średnia podróż transportem publicznym trwa 38 minut, a w aglomeracji 48 minut. Prawdopodobnie wynika to z wykorzystania różnych środków transportu. Paryż ma dość gęstą sieć metra z przystankami w bardzo niedużej odległości, a aglomeracja jest obsługiwana przez kolej regionalną, na której przystanki są rzadsze, a zatem i prędkość może być większa. Dla porównania średni dystans wszystkich podróży w aglomeracji to $4,4 \mathrm{~km}$, a średni czas to 24 minuty.

\subsection{Wiedeń}

Wiedeń podobnie jak Paryż jest zdecydowanie pieszym miastem. Ruch pieszy odpowiada w nim za $28 \%$ podróży (Stadtentwicklung und Stadtplanung Wien, 2015). Podobnie jak w Paryżu czy Londynie ruch rowerowy jest w nim stosunkowo niski jednak i tak odpowiada za 6\% podróży. Transportem publicznym wykonywanych jest 38\% podróży. Również podobnie jak w Paryżu czy Londynie widać różnice między średnią dla miasta i dzielnicami centralnymi (Ryc. 4.), czyli nowożytną częścią miasta do obwodnicy Gürtel (promień 2,5km od centrum). W dzielnicach tych średni udział ruchu pieszego sięga 33\% (20-40\% w poszczególnych dzielnicach), a udział ruchu rowerowego $9 \%$ (3-15\% w poszczególnych dzielnicach). Warto jednak zauważyć, że ruch rowerowy jest niski $(3 \%)$ na samym starym mieście, gdzie jest dużo stref pieszych. Transport zbiorowy we wszystkich dzielnicach odpowiada za około $40 \%$ podróży. Podobnie jak w Berlinie i Paryżu Wiedeńczycy chodzą pieszo przede wszystkim na zakupy (51\% podróży w przypadku zakupów podstawowych i $34 \%$ podróży w przypadku zakupów pozostałych) oraz do miejsc nauki (26\% podróży). Duży jest także udział ruchu pieszego w podróżach związanych z miejscami spędzania czasu wolnego (gastronomia, kultura - 31\%) oraz ze sportem i wypoczynkiem (24\%). Podróże piesze są jednak dość krótkie. Średnio w skali miasta odbywają się na dystansie $0,8 \mathrm{~km}$. Podróże piesze stanowią $99 \%$ podróży na dystansie do $500 \mathrm{~m}$ i $77 \%$ podróży na dystansie $500-1000 \mathrm{~m}$. Na dystansie $1-2 \mathrm{~km}$ podróże piesze to $32 \%$ podróży, a na dystansie $2-3 \mathrm{~km}$ to $14 \%$ podróży. Na dłuższych dystansach podróże piesze są już bardzo rzadkie. Ogólnie prawie 80\% wszystkich podróży pieszych odbywa się na dystansie do $1 \mathrm{~km}$. Podróże rowerowe są nieco dłuższe. Średnio mają długość $2,8 \mathrm{~km}$. Na dystansie do $500 \mathrm{~m}$ stanowią $1 \%$ podróży, na dystansie $500-1000 \mathrm{~m} 8 \%$ podróży, a na dystansie 1-2km 15\% podróży. Następnie udział podróży rowerowych zaczyna maleć. Na dystan- 
sie 2-3km podróże rowerowe stanowią $9 \%$ wszystkich podróży, na dystansie $3-5 \mathrm{~km} 6 \%$, a na dystansie $7-8 \mathrm{~km} 7 \%$. Dłuższe podróże są już dość rzadkie. Ogólnie $80 \%$ wszystkich podróży rowerowych odbywa się na dystansie do $5 \mathrm{~km}$. Średni dystans pokonywany transportem publicznym to $5,6 \mathrm{~km}$, a średni dystans wszystkich podróży w mieście to $4 \mathrm{~km}$. Jeśli chodzi o czas podróży to średnia podróż piesza trwa w Wiedniu 18 minut, a $80 \%$ podróży pieszych mieści się w przedziale do 20 minut. Średnia podróż rowerowa trwa 21 minut, a $75 \%$ podróży rowerowych mieści się w przedziale do 20 minut. Średnia podróż transportem publicznym trwa 37 minut, a $73 \%$ podróży tym transportem mieści się $\mathrm{w}$ przedziale do 40 minut.

\subsection{Warszawa}

Warszawa w tym zestawieniu znalazła się głównie ze względów porównawczych (Ryc. 4.). Udział „aktywnej mobilności” we wszystkich podróżach wynosi $21 \%$. Większość z tych podróży to podróże piesze, które stanowią $18 \%$ wszystkich podróży. To podobny udział jak w Amsterdamie czy Kopenhadze tylko tam istotnym środkiem transportu jest także rower. W Warszawie transport rowerowy to tymczasem zaledwie $3 \%$ podróży. Warto tu wspomnieć, że jeszcze na początku lat 90-tych XX wieku udział ruchu pieszego w Warszawie sięgał około 30\% (BPMiT, 2016). Od tego czasu zmalał na rzecz transportu samochodowego. Najprawdopodobniej ten dawniej wysoki udział wynikał w dużej mierze z braku dostępności transportu samochodowego, a nie z preferencji mieszkańców. Udział transportu zbiorowego jest w Warszawie dość wysoki i wynosi $47 \%$. Warszawa nie zbiera zbyt wielu szczegółowych danych dotyczących ruchu pieszego. Z Warszawskiego Badania Ruchu (WBR) możemy się tylko dowiedzieć, że większość podróży pieszych do pracy dobywa się na dystansie do $2,5 \mathrm{~km}$, a najwięcej (około $60 \%$ ) do $1 \mathrm{~km}$. Podróże do miejsc nauki są trochę dłuższe, nawet do $3 \mathrm{~km}$, ale też najwięcej (około $80 \%$ ) odbywa się na dystansie do $1 \mathrm{~km}$. WBR podaje także dane o niektórych dystansach bez przypisywania im środka transportu. Podobnie jak $w$ innych miastach podróże do miejsc podstawowych zakupów i usług, a także miejsc rozrywki są dość krótkie. Ponad $40 \% \mathrm{z}$ nich odbywa się na dystansie do $1 \mathrm{~km}$, a ponad $70 \%$ na dystansie do $3 \mathrm{~km}$. Podróże do pracy są dłuższe i najczęściej odbywają się na dystansie $5-8 \mathrm{~km}$. Ogólnie podróż piesza trwa w Warszawie średnio 14 minut, a $76 \%$ podróży pieszych mieści się w przedziale do 15 minut. Średnia podróż rowerowa trwa 25 minut, a 78\% podróży rowerowych mieści się w przedziale do 30 minut. Średnia podróż transportem publicznym trwa 41 minut, a $68 \%$ podróży transportem publicznym mieści się w przedziale do 45 minut.

\section{PODSUMOWANIE I WNIOSKI}

\subsection{Wnioski dotyczące ruchu pieszego}

Porównanie badań dotyczących dystansów w mieście z badaniami dotyczącymi mobilności w europejskich miastach potwierdza, że podróże piesze najczęściej odbywają się na dystansie do 400$900 \mathrm{~m}$ choć różnie wygląda to różnych miastach (Ryc. 5.). Na przeszkodzie dokładniejszego określenia dystansu pieszego stoi także różny sposób mierzenia ruchu w różnych miastach. Na przykład badanie kopenhaskie, gdzie najkrótszy badany dystans to $2 \mathrm{~km}$ nie daje odpowiedzi mogących ocenić jaki jest dystans pieszy $w$ tym mieście. $Z$ drugiej strony zebrane dane potwierdzają, że maksymalny dystans pieszy to około 2-3km (Ryc. 5.). Również czas podróży pieszej jest wszędzie podobny i wynosi około 15 minut. Potwierdza to użyteczność podziału dystansów na podstawowy, standardowy i maksymalny, które często są też powiązane z różnymi celami podróży np. dystans podstawowy związany jest $z$ dojściem do szkoły, a dystans standardowy $z$ dojściem do miejsca pracy lub spędzania wolnego czasu. Ciekawy jest przykład Paryża, gdzie przy średniej długości podróży w okolicach $400 \mathrm{~m}$ średni jej czas to 12 minut. To oznaczałoby, że mieszkańcy Paryża chodzą pieszo o połowę wolniej niż standardowo przyjmowana prędkość 4-5km/h. Być może ma na to wpływ duży udział podróży pieszych do szkoły (dzieci chodzą wolniej), a może też w mieście są jednak bariery (np. długie oczekiwanie na światłach), które spowalniają podróż pieszą. To pokazuje, że planując miasto pod kątem podróży pieszych trzeba wziąć pod uwagę więcej czynników niż tylko odległość. Zwraca także uwagę niski udział podróży pieszych w miastach o dużej liczbie podróży rowerowych. Pokazuje to, że chociaż ruch pieszy i rowerowy są zaliczane razem do „ak- 
tywnej mobilności" to jednak w określonych przypadkach konkurują ze sobą. Dotyczy to zarówno konkurencji o wybór danego środka transportu jak i konkurencji o przestrzeń co pokazuje przykład starych miast w Amsterdamie i Wiedniu.

\subsection{Wnioski dotyczące ruchu rowerowego}

Analiza danych dotyczących ruchu rowerowego pozwala wyznaczyć dodatkowy dystans do $2 \mathrm{~km}$ (Ryc. 5.), który można nazwać dystansem podstawowym, na którym często ruch rowerowy konkuruje z ruchem pieszym. Poza tym potwierdza się, że podróże rowerowe bardzo często obejmują dystans do $3-5 \mathrm{~km}$ (warto zauważyć, że niektóre analizowane miasta mają granice administracyjne w promieniu $5 \mathrm{~km}$ od centrum), który można nazwać standardowym dystansem rowerowym (Ryc. 5.), a dystans maksymalny to zazwyczaj około 7-10km (Ryc. 5.). Dłuższe podróże częściej wykonują mieszkańcy aglomeracji Kopenhagi co pewnie można wiązać z rozwiniętą infrastrukturą rowerową. Ciekawe jest również to, że o ile podróże piesze do pracy są dość rzadkie to rower w tego typu podróżach często konkuruje z transportem publicznym oraz samochodowym. Podróże rowerowe są też dłuższe czasowo niż piesze i trwają średnio około 20 minut. Za średnią prędkość rowerową w mieście powinno przyjmować się około $15-16 \mathrm{~km} / \mathrm{h}$. W częściach miasta o wyższym udziale ruchu pieszego prędkość ta jest raczej bliższa $10 \mathrm{~km} / \mathrm{h}$, a na terenach bardziej oddalonych od centrum może przekraczać $20 \mathrm{~km} / \mathrm{h}$.

\subsection{Wnioski dotyczące transportu publicznego}

Transport publiczny jest bardzo zróżnicowany w opisywanych miastach. Jego cechą wspólną jest jednak dłuższa odległość pokonywana z jego wykorzystaniem, często $10 \mathrm{~km}$ i więcej, a także dłuższy czas podróży, często 40 minut i więcej. Być może tym da się wytłumaczyć wyższy udział transportu zbiorowego w rozleglejszych miastach i aglomeracjach takich jak Berlin, Wiedeń czy aglomeracja paryska. Badania $z$ europejskich miast potwierdzają także, że skłonność dłuższego dojścia do danego środka transportu jest zależna od jego rodzaju.

\subsection{Wnioski dotyczące wymiarów jednostek urbanistycznych}

Porównując dystanse piesze i rowerowe do wymiarów jednostek urbanistycznych z różnych projektów teoretycznych (Ryc. 6.)trzeba przyznać, że najbardziej trafnie wymiary miasta zaproponował Ebenezer Howard, którego miasto-ogród mieści się w maksymalnym dystansie pieszym i podstawowym dystansie rowerowym. Bardzo dobrze bronią się też wymiary zaproponowanej przez Clarence'a Perry'ego ,jednostki sąsiedzkiej” oraz wymiary osiedla proponowane przez Leona Kriera, które w obu wypadkach mieszczą się w standardowym dystansie pieszym (Ryc. 5.). W standardowym dystansie pieszym zarówno odległościowym jak i czasowym mieszczą się także jednostki urbanistyczne zaproponowane przez Victora Gruena. W zakładanych dystansach bardzo „oszczędni” byli natomiast Arturo Soria y Mata z projektem „miasta liniowego” oraz Peter Calthorpe z ideą „Transit Oriented Development” (TOD). „Miasto liniowe” mogłoby być dwukrotnie szersze, a i tak mieściłoby się w zasięgu standardowego dystansu pieszego (na szerokość). Natomiast osiedle TOD przyjmuje te same wymiary niezależnie od obsługującego je środka transportu, a dystans dla np. przystanku linii kolejowej mógłby być o kilkaset metrów większy. Dystanse do targowisk Barcelony zaproponowane przez Ildefonsa Cerdę są już raczej nieaktualne. Być może 100 lat temu ludzie byli skłonni przeznaczać 30 minut i więcej na dojście do dość podstawowych funkcji. Dziś być może pokonaliby taki dystans rowerem, ale na pewno cześć zdecydowałaby się na transport zmechanizowany. Zaproponowana przez Yacova Zahaviego idea "budżetu czasowego” sprawdza się tylko częściowo. Wyraźnie widać, że ludzie są skłonni poświęcić mniej czasu na podróż związaną z "aktywną mobilnością" niż na podróż zmechanizowaną. W tym pierwszym przypadku to około 20 minut podróży, a w tym drugim nawet dwukrotnie więcej. Podważa to też częściowo „stałą Marchettiego". Wprawdzie rzeczywiście sprawdza się ona przy historycznym opisie rozwoju miast, gdyż nawet dziś dzielnice takich miast jak Paryż czy Wiedeń, które są położone w zasięgu 30 minut marszu od centrum mają wyższy udział „aktywnej mobilności”. Jednak w praktyce ludzie poświęcają więcej czasu na podróż pieszą lub rowerową tylko wtedy kiedy nie mają innego wyboru lub robią to dla rekreacji. „Stała Marchettiego" wyznacza zatem maksymalny dystans pieszy, ale nie może być wykorzystywana jako prosty wzorzec do projektowania wielkości 
jednostek urbanistycznych. Nie oznacza to jednak, że branie pod uwagę wymiaru czasu w planowaniu przestrzennym jest nieistotne, wręcz przeciwnie. To właśnie czas podróży w różnych miastach wykazuje większą zbieżność niż odległość tej podróży. Dlatego sensowne wydaje się rozwijanie zaproponowanej przez Carlosa Moreno idei „chronourbanizmu”. Jest ona o wiele bardziej wymagająca dla urbanistów, ponieważ nie opiera się na prostych wytycznych dotyczących odległości, ale wymaga by dostosować ją do czasu jaki mieszkaniec miasta jest skłonny przeznaczyć na jej pokonanie. Nie można także przyjmować stałej prędkości dla danego środka transportu np. ruchu pieszego lub rowerowego, ponieważ różni się ona pomiędzy obszarami miasta, a także zależy od tego kim jest dany użytkownik. Można też dyskutować czy zaproponowane przez Moreno 15 minut to jednak nie mało. Bardziej realistyczne są chyba założenia Singapuru czy Melbourne, które rozwijają idee "miasta 20-minutowego”. Przekładając to jednak na rzeczywiste wymiary badania z europejskich miast sugerują, że wymiary „dzielnicy 15-minutowej” o promieniu około $1200 \mathrm{~m}$, który można rozciągnać do $1500 \mathrm{~m}$, zaproponowane przez Andreasa Duany'ego i Roberta Steuteville'a można uznać za dość poprawne. W dodatku mieszczące się w standardowym dystansie pieszym. Ryzykowne wydają się jednak przyjmowane przez nich wymiary „miasta rowerowego” oparte na założeniu, że użytkownicy rowerów poruszają się z prędkościami rzędu $20 \mathrm{~km} / \mathrm{h}$. Badania europejskie pokazują, że średnia prędkość to raczej około $15 \mathrm{~km} / \mathrm{h}$, a przy krótkich podróżach (Duany i Steuteville opisują podróże 5-minutowe) prędkość może być mniejsza, bliższa $10 \mathrm{~km} / \mathrm{h}$. Wówczas 5-minutowa podróż rowerowa to około $800-1200 \mathrm{~m}$, a 10 -minutowa to $1,6-2,5 \mathrm{~km}$. Z drugiej strony, ponieważ podróże rowerowe zazwyczaj są dłuższe, a rower częściej jest wykorzystywany np. jako środek transportu do pracy to być może miasto 15- lub 20-minutowe powinno mieć różne "warstwy" - pieszą i rowerową z różnymi funkcjami dostępnymi różnymi środkami transportu. W ten sposób okazuje się, że miasto 15- lub 20-minutowe bardzo dobrze łączy się z pojęciem dystansów zaproponowanych przez Hugh Bartona, który różnicuje je w zależności od miejsc docelowych dzieląc miasto na osiedle o wymiarach odpowiadających standardowemu dystansowi pieszemu (dystanse do $1000 \mathrm{~m}$ ) oraz dzielnicę/miasto o wymiarach standardowego dystansu rowerowego (dystanse do $5 \mathrm{~km}$ ). Dla obsługi usług wyższego rzędu zapewne należałoby wprowadzić transport publiczny. Analiza opisanych w artykule teorii oraz danych europejskich miast prowadzi do wniosku, że dostęp do różnych funkcji w mieście należy uzależnić od środka transportu używanego do dotarcia do danej funkcji. Funkcje podstawowe takie jak przedszkole, szkoła podstawowa, podstawowa opieka zdrowotna oraz sklepy z podstawowymi produktami i podstawowe miejsce rekreacji np. plac zabaw czy boisko powinny znaleźć się jak najbliżej miejsca zamieszkania. Najlepiej by były w odległości nie większej niż podstawowy dystans pieszy, czyli 800-900m (Ryc. 5.). Taka powinna być skala osiedla, najlepiej nie przeciętego żadną ruchliwą ulicą. Usługi rzadziej odwiedzane jak np. sklepy odzieżowe, a także duże miejsca rekreacji (baseny, kluby sportowe), ale także miejsca rozrywki (np. kino), kultury czy gastronomia mogą znajdować się w większej odległości. Nie powinna ona jednak przekraczać 3-5km co koresponduje z podstawowym dystansem rowerowym i maksymalnym dystansem pieszym (około $3 \mathrm{~km}$ ) oraz ze standardowym dystansem rowerowym (około $5 \mathrm{~km})($ Ryc. 5.). Dystans 3-5km wyznacza wielkość dzielnicy, która pozwala zaspokajać większość potrzeb życiowych bez konieczności korzystania z transportu zmechanizowanego. Usługi rzadko odwiedzane jak sklepy specjalistyczne czy miejsca kultury wysokiej (filharmonie, muzea), a przede wszystkim miejsca pracy mogą być położone znacznie dalej, najlepiej do $10 \mathrm{~km}$ od miejsca zamieszkania, ale mogą też być położone nawet dalej. Jednak w ich przypadku znacznie ważniejszy od samego dystansu jest czas podróży, a ten może być różny dla różnych środków transportu. Najlepiej gdy czas takiej podróży nie przekracza 40-50 minut. Najważniejsze jest to w przypadku codziennych dojazdów do pracy. Dlatego też nie należy się spodziewać, że dużo ludzi będzie chodzić do pracy. Jeśli już mieszkańcy będą wykorzystywać jakieś środki aktywnej mobilności w podróżach do pracy to będzie to raczej rower. Ogólnie należy przyjąć, że aktywna mobilność będzie dominować w krótkich podróżach do 2-3km. Przy dużym udziale transportu rowerowego podróże mogą być dłuższe i nawet przekraczać $5 \mathrm{~km}$. Trzeba jednak założyć, że od tych $2-3 \mathrm{~km}$ będzie rósł udział transportu zmechanizowanego. Najlepiej, jeśli będzie to transport zbiorowy. By tak się jednak działo konieczne jest odpowiednie powiązanie sieci transportu zbiorowego ze strukturą miasta. Przede wszystkim odległość do przystanków kolei, metra i tramwaju nie powinna być większa niż podstawowy dystans pieszy. Dla autobusów ta odległość powinna być o połowę mniejsza. Same miejsca pracy $\mathrm{i}$ inne usługi ponadlokalne powinny być sytuowane w miejscach, do których łatwo 
dojechać z różnych stron miasta. Co ciekawe takim „modelowym” miastem wydaje się być posiadający policentryczną strukturę Berlin, gdzie prawie połowa podróży jest związana z „aktywną mobilnością", a duża część pozostałych odbywa się z wykorzystaniem transportu publicznego. Jak widać nawet bardzo duże miasto może być miastem krótkich dystansów przy czym należy mieć świadomość, że ten „krótki dystans” nie zawsze znaczy to samo.

\section{BIBLIOGRAPHY}

Apodaca-Cahalane M., 2015, Ildefons Cerdà: The True Founder of Comprehensive Planning; Bloustein Review, 2015, dostęp przez: https://blousteinreview.rutgers.edu/ildefons-cerda-the-true-founder-ofcomprehensive-planning/, Dostęp/access: 2021.02.28

Barton H., Grant M., Guise R., 2003, Shaping Neighbourhoods For Local Health and Global Sustainability, Routledge, Nowy Jork,

Bernardi S., Rupi F., 2013, An analysis of bicycle travel speed and disturbances on off-street and on-street facilities; Transportation Research Procedia 5 ( 2015 ) s. 82 - 94, Elsevier, dostęp przez: https://core.ac.uk/download/pdf/82484444.pdf, Dostęp/access: 2021.02.28

Biuro Polityki Mobilności i Transportu m.st. Warszawy [BPMiT], 2016, Warszawskie Badanie Ruchu 2015, Synteza, Warszawa, dostęp przez https://transport.um.warszawa.pl/sites/default/files/WBR\%202015\%20SYNTEZA\%20POL.pdf, Dostęp/access: 2021.03.01

Biuro Polityki Mobilności i Transportu m.st. Warszawy [BPMiT], 2016, Warszawskie Badanie Ruchu 2015, Raport z etapu III, Warszawa, dostęp przez: http://transport.um.warszawa.pl/sites/default/files/WBR\%202015.\%20Etap\%20III.\%20Raport.\%20Wersja\% 2006_2016.pdf, Dostęp/access: 2021.03.01

Boileau I., 1959, La Ciudad Lineal: A Critical Study of the Linear Suburb of Madrid; The Town Planning Review, Vol. 30, No. 3 (Oct., 1959), Liverpool University Press, pp. 230-238

Byun N., Choi Y., Choi J., 2014, The Neighborhood Unit:Effective or Obsolete?; DOI:10.3130/jaabe.13.617s; Journal of Asian Architecture and Building Engineering, 13:3, s. 617-624, Architectural Institute of Japan

Calthorpe P., 1993, The Next American Metropolis: Ecology, Community, and the American Dream, Princeton Architectural Press, Nowy Jork, ISBN 1-878271-68-7

Capital Region of Denmark, 2017, Cycling report for the Capital Region 2016. Copenhagen, dostęp przez: https://www.regionh.dk/til-

fag-

folk/trafik/Cykler/Documents/19129\%20Cykelregnskab\%202017_A4\%20bred_ENG_enkeltsider_final.pdf, Dostęp/access: 2021.03.01

City of Copenhagen, 2011, Copenhagen. City of Cyclists. Facts \& Figures. Bicycle Account 2010, Copenhagen: Technical and Environmental Administration, dostęp przez: https://kk.sites.itera.dk/apps/kk_pub2/?mode=detalje\&id=1036, Dostęp/access: 2021.03.01

City of Copenhagen, 2017, Copenhagen. City of Cyclists. Facts \& Figures. Copenhagen: Technical and Environmental Administration, dostęp przez: https://international.kk.dk/sites/international.kk.dk/files/velocity_handout.pdf,_Dostęp/access: 2021.03.01

CyclingUK, 2021, Cycling UK's Cycling Statistics, dostęp przez: https://www.cyclinguk.org/statistics, Dostęp: 2021.03.01

Daniels R., Mulley C., 2013, Explaining walking distance to public transport: The dominance of public transport supply; DOI: https://doi.org/10.5198/jtlu.v6i2.308, Journal of Transport and Land Use, 6(2), s. 5-20.,

Department for Transport, Transport Statistics Great Britain 2017, Londyn, dostęp przez: https://assets.publishing.service.gov.uk/government/uploads/system/uploads/attachment_data/file/661933/ tsgb-2017-report-summaries.pdf, Dostęp/access: 2021.03.01 
Department for Transport, 2019, Walking and Cycling Statistics, England: 2018, Londyn, dostęp przez: https://assets.publishing.service.gov.uk/government/uploads/system/uploads/attachment_data/file/821842/ walking-and-cycling-statistics-2018-accessible.pdf, Dostęp/access: 2021.03.01

Direction régionale et interdépartementale de l'équipement et de l'aménagement d'île-de-France (DRIEA), 2013, Enquête globale transport, Paryż, dostęp przez http://www.driea.ile-de-france.developpementdurable.gouv.fr/egt-2010-mobilite-selon-les-modes-profils-de-a4155.html, Dostęp/access: 2021.03.01

Dolati H., 2014, Biking Distance: Exploring Gender, Race, and Climate, The Ohio State University, dostęp przez: http://rave.ohiolink.edu/etdc/view?acc_num=osu1388725654, Dostęp/access: 2021.03.01

Duany A., Steuteville R., 2021, Defining the 15-minute city; Public Square, dostęp przez: https://www.cnu.org/publicsquare/2021/02/08/defining-15-minute-city, Dostęp/access: 2021.02.28

El-Geneidy A., Grimsrud,M., Wasfi R., Tétreault P., Surprenant-Legault J., 2014, New evidence on walking distances to transit stops: Identifying redundancies and gaps using variable service areas, . https://doi.org/10.1007/s11116-013-9508-z, Transportation, 41(1), s. 193-210.

Eriksson J., Forsman Å., Niska A., Gustafsson S., Sörensen G., 2019, An analysis of cyclists' speed at combined pedestrian and cycle paths, DOI: 10.1080/15389588.2019.1658083, Traffic Injury Prevention, 20:sup3, s. 56-61,

Gemeente Amsterdam, 2019, Amsterdamse Thermometer van de Bereikbaarheid 2019, dostęp przez: https://www.amsterdam.nl/bestuur-organisatie/volg-beleid/verkeer-vervoer/bereikbaarheid/, Dostęp/access: 2021.02.28

Gruen V., 1964, The Heart of Our Cities: The Urban Crisis: Diagnosis and Cure, Simon and Schuster, Nowy Jork

de Haas M., Hamersma M., 2019, Walking Facts, Netherlands Institute for Transport Policy Analysis (KiM), Haga, ISBN 978-90-8902-215-8, dostęp przez: https://english.kimnet.nl/publications/publications/2019/10/3/walking-facts, Dostęp/access: 2021.02.28

Howard E., przekład pod redakcją Pieńkos J., Myśliwiec J., Miasta-ogrody jutra, Fundacja Centrum Architektury, Instytut Kultury Miejskiej, Warszawa, Gdańsk, ISBN:978-83-943750-0-3

Instytut Rozwoju Miast (IRM), 2017, Raport o stanie polskich miast Zarządzanie $i$ współpraca w miejskich obszarach funkcjonalnych, dostęp przez: http://obserwatorium.miasta.pl/wpcontent/uploads/2017/10/OPM_IRM_Zarz\%C4\%85dzanie-i-wsp\%C3\%B3\%C5\%82praca-w-miejskichobszarach-funkcjonalnych_Raport-o-stanie-polskich-miast_2017.pdf, Dostęp/access: 2021.03.01

Krier L., Przekład pod redakcją: Jaworska M., 2011, Architektura Wspólnoty, Wydawnictwo słowo/obraz terytoria, Gdańsk, ISBN 978-83-7453-0540-5

Land Transport Authority, Singapur, 2020, Land Transport Master Plan 2040, dostęp przez: https://www.Ita.gov.sg/content/ltagov/en/who_we_are/our_work/land_transport_master_plan_2040.html, Dostęp/access: 2021.02.28

Larsen J., El-Geneidy A., Yasmin F., 2010, Beyond the quarter mile: Re-examining travel

distances by active transportation; Canadian Journal of Urban Research: Canadian Planning

and Policy, 19(1), s. 70-88

Marchetii C., 1994, Anthropological invariants in travel behawior, https://doi.org/10.1016/0040-1625(94)900418, Technological Forecasting and Social Change, Volume 47, Issue 1, Elsevier

Moreno C., 2019, The 15 minutes-city: for a new chrono-urbanism!, dostęp przez: http://www.morenoweb.net/the-15-minutes-city-for-a-new-chrono-urbanism-pr-carlos-moreno/, Dostęp/access: 2021.02.28

Nello-Deakin S., Nikolaeva A., 2020, The human infrastructure of a cycling city: Amsterdam through the eyes of international newcomers, DOI: 10.1080/02723638.2019.1709757,

Urban Geography,

Office for National Statistics (ONS), 2014, Travel to Work by Bicycle, Ward, dostęp przez: https://data.Iondon.gov.uk/dataset/travel-work-bicycle-ward, Dostęp/access: 2021.03.01

Olszewski P.S., 2007, Walking as a mode of transport - a planning and policy perspective, Oficyna Wydawnicza Politechniki Warszawskiej, Warszawa, ISSN 0137-2297

Project for Public Spaces (PPS), 2014, Market Cities: Barcelona Offers a Hopeful Glimpse of the Future, dostęp przez: https://www.pps.org/article/market-cities-barcelona-offers-a-hopeful-glimpse-of-the-future, Dostęp/access: 2021.02.28

Schaap N., Harms L., Kansen M, Wüst H., 2016, Cycling and walking: the grease in our mobility chain, KiM Netherlands Institute for Transport Policy Analysis, Ministry of Infrastructure and the Environment, The Hague, ISBN: 978-90-8902-145-8 
Schantz P., 2017, Distance, Duration, and Velocity in Cycle Commuting: Analyses of Relations and Determinants of Velocity, https://doi.org/10.3390/ijerph14101166, International Journal of Environmental Research and Public Health, 14(10), 1166;

Senatsverwaltung für Umwelt, Verkehr und Klimaschutz, 2019, Mobilität in Städten - System repräsentativer Verkehrsbefragungen (SrV) 2018, dostęp przez:

https:/www.berlin.de/sen/uvk/verkehr/verkehrsdaten/zahlen-und-fakten/mobilitaet-in-staedten-srv-2018/, Dostęp/access: 2021.03.01

Stadtentwicklung und Stadtplanung Wien, 2015, Zu Fuß gehen in Wien, Wien: Omnitrend, dostęp przez: https://www.wien.gv.at/stadtentwicklung/studien/pdf/b008453a.pdf, Dostęp/access: 2021.03.01

State Government of Victoria, 2016, Plan Melbourne 2017-2050, dostęp przez: https://www.planmelbourne.vic.gov.au/, Dostęp/access: 2021.02.28

Ton D., Duives D.C., Cats O., Hoogendoorn-Lanser S., Hoogendoorn S.P., 2019, Cycling or walking? Determinants of mode choice in the Netherlands, https://doi.org/10.1016/j.tra.2018.08.023, Transportation Research Part A: Policy and Practice, Volume 123, Pages 7-23, ISSN 0965-8564,

Ton D., Cats O., Duives D.C., Hoogendoorn S.P., 2017, How do people cycle in

Amsterdam? Estimating cyclists' route choice determinants using GPS data from an urban area, DOI: 10.3141/2662-09, Transportation Research Record: Journal of Transportation Research Board, January 2017

Transport for London, 2018, Travel in London, Report 11, dostęp przez: http://content.tfl.gov.uk/travel-inlondon-report-11.pdf, Dostęp/access: 2021.03.01

Willsher K., 2020, Paris mayor unveils '15-minute city' plan in re-election campaign; The Guardian, dostęp przez: https://www.theguardian.com/world/2020/feb/07/paris-mayor-unveils-15-minute-city-plan-in-reelection-campaign, Dostęp/access: 2021.02.28

Zahavi Y., Talvitie A., 1980, Regularities in Travel Time and Money Expenditures, w: Household activities, budget constraints, and stability of travel; Transportation Research Record, Issue Number: 750, Transportation Research Board, ISSN: 0361-1981

\section{AUTHOR'S NOTE}

MSc. Arch. Leszek S. Wiśniewski - a graduate of the Faculty of Architecture of the Warsaw University of Technology and the Institute of Public Space Research at the Academy of Fine Arts in Warsaw. Currently an assistant at the Department of Urban Planning and Rural Landscape at the Faculty of Architecture of the Warsaw University of Technology. In his research activity he deals with combining spatial planning with various types of transport. Author of a master's thesis awarded by the Minister of Infrastructure, which subject was the design of a new urban district around the remodeled railway junction. He also cooperates with some non-governmental organizations, such as the "Miasto Jest Nasze" Association, the SISKOM Association, the Jagiellonian Club and Client Earth. 


\section{O AUTORZE}

mgr inż. arch. Leszek S. Wiśniewski - absolwent Wydziału Architektury Politechniki Warszawskiej oraz Instytutu Badania Przestrzeni Publicznej Akademii Sztuk Pięknych w Warszawie. Obecnie asystent w Katedrze Projektowania Urbanistycznego i Krajobrazu Wiejskiego Wydziału Architektury Politechniki Warszawskiej. Zajmuje się łączeniem planowania przestrzennego z różnego rodzajami transportu. Autor pracy magisterskiej nagrodzonej przez Ministra Infrastruktury, której tematem była budowa nowej dzielnicy wokół przekształconego węzła kolejowego. Współpracuje także z innymi organizacjami pozarządowymi np. Stowarzyszeniem "Miasto Jest Nasze", Stowarzyszeniem SISKOM, Klubem Jagiellońskim i Client Earth.

Contact | Kontakt: leszek.wisniewski@pw.edu.pl 